Illinois State University

ISU ReD: Research and eData

Theses and Dissertations

$3-24-2020$

\title{
Hemodynamic Effects Of Graston Technique On Trigger Points In The Upper Trapezius In Patients With Neck Pain
}

Hannah Harris

Illinois State University, hanharris3@gmail.com

Follow this and additional works at: https://ir.library.illinoisstate.edu/etd

Part of the Kinesiology Commons

\section{Recommended Citation}

Harris, Hannah, "Hemodynamic Effects Of Graston Technique On Trigger Points In The Upper Trapezius In Patients With Neck Pain" (2020). Theses and Dissertations. 1223.

https://ir.library.illinoisstate.edu/etd/1223

This Thesis is brought to you for free and open access by ISU ReD: Research and eData. It has been accepted for inclusion in Theses and Dissertations by an authorized administrator of ISU ReD: Research and eData. For more information, please contact ISUReD@ilstu.edu. 


\section{HEMODYNAMIC EFFECTS OF GRASTON TECHNIQUE ON TRIGGER POINTS IN THE UPPER TRAPEZIUS IN PATIENTS WITH NECK PAIN}

\section{HANNAH HARRIS}

56 Pages

Background: Non-specific neck pain (NS-NP) is defined as neck pain without a specific diagnosis with varying causes such as poor posture, occupational stressors, and muscular trigger points. Individuals often present with poor posture, including forward head and rounded shoulders. In this position, the upper trapezius muscle becomes tight due to sustained muscle activity leading to trigger points as a result of decreased oxygen to the muscle. Graston Technique ${ }^{\circledR}(\mathrm{GT})$ is a form of manual therapy that uses stainless steel instruments to break down tissue adhesions. GT on trigger points has been presumed to increase local blood flow leading to tissue healing and decreased pain, however, the physiological effects on muscle hemodynamics have yet to be proven.

Objective: To measure active cervical range of motion, neck pain, and subcutaneous hemodynamics of the upper trapezius following a single intervention of GT in patients with neck pain stemming from trigger points.

Participants: Sixty participants between the ages of 18-40 years old with NS-NP and trigger point(s) present in the upper trapezius muscle. Participants were excluded if they had manual therapy treatment within the past 3 months to the neck or shoulder area, history of a diagnosed neck injury, history of spinal or shoulder surgery, cancer, kidney dysfunction, 
pregnancy, taking an anticoagulant medication, varicose veins, polyneuropathies, diabetes, heart failure, contagious skin conditions, open wounds, thrombophlebitis, and hypertension.

Methods: Participants were allocated into one of the following groups: GT, sham instrument assisted soft tissue mobilization (IASTM), or control. All participants completed the GT protocol which included: a 10-minute arm bike warm, 5-minute treatment based on group allocation, passive lateral flexion stretch, and 3 therapeutic exercises. Treatment area was determined by bilateral palpation of the upper trapezius muscle for the most prominent trigger point.

Results: There were increased levels of oxygenated hemoglobin at superficial and deep depths in the GT and sham groups $(\mathrm{p} \leq 0.008)$ compared to the control group. However, there were no differences found between GT and sham ( $\mathrm{p} \geq 0.555)$. For ipsilateral lateral flexion, there was no treatment main effect $(\mathrm{p}=0.126)$, however GT showed increased ROM compared to control $(p=0.043)$ with post-hoc testing. For contralateral lateral flexion, there was a main effect $(\mathrm{p}=0.001)$, where GT and sham showed increased ROM compared to the control, $\mathrm{p} \leq 0.001$ and $\mathrm{p}=0.019$, respectively. There were no differences among groups for PPT $(\mathrm{p}=.201)$.

Conclusion: Overall, GT proved to be an effective treatment technique on subcutaneous hemodynamics and ROM in the upper trapezius muscle in patients with neck pain. After a single treatment of GT, participants received increased blood flow to the upper trapezius and increased neck range of motion. Further research is needed to establish GT as a superior treatment to other forms of instrument assisted soft tissue mobilization.

KEYWORDS: blood flow, instrument assisted soft tissue mobilization (IASTM), manual therapy 


\title{
HEMODYNAMIC EFFECTS OF GRASTON TECHNIQUE ON TRIGGER POINTS IN THE UPPER TRAPEZIUS IN PATIENTS WITH NECK PAIN
}

\author{
HANNAH HARRIS
}

\begin{abstract}
A Thesis Submitted in Partial
Fulfillment of the Requirements for the Degree of

\section{MASTER OF SCIENCE}

School of Kinesiology and Recreation

ILLINOIS STATE UNIVERSITY
\end{abstract}


Copyright 2020 Hannah Harris 


\title{
HEMODYNAMIC EFFECTS OF GRASTON TECHNIQUE ON TRIGGER POINTS IN THE UPPER TRAPEZIUS IN PATIENTS WITH NECK PAIN
}

\author{
HANNAH HARRIS
}

COMMITTEE MEMBERS:

Noelle Selkow, Chair

Justin Stanek 


\section{ACKNOWLEDGMENTS}

First, I would like to thank my thesis chair and advisor Dr. Noelle Selkow, Interim Director of the Graduate School and Director of Graduate Athletic Training Education at Illinois State University. Among the various duties she is obligated to perform, Dr. Selkow consistently aided myself and others through the process of completing a thesis. She displayed a caring nature while driving me to strive for excellence and provided help every step through this process. I am grateful to Dr. Selkow for providing such a vigorous and supporting environment to achieve my goals with this thesis.

Secondly, I am thankful to my thesis co-chair and mentor Dr. Justin Stanek, Undergraduate Athletic Training Program Director at Illinois State University. Dr. Stanek was there to answer additional questions I had throughout this process among other topics of my professional career. He has been an educator and mentor of mine for the past five years and has always provided support and advice along the way. Dr. Stanek has guided me through my journey of the athletic training profession and has always pushed me to reach my potential.

Lastly, I am beyond grateful for my friends and family for supporting me throughout not only this process but in life. The friends and family I have been so blessed with have always ensured I was loved, supported, and driven to succeed. My gratitude to those individuals will never be explained properly as they have helped me become who I am today. I would not be able to have reached this goal without their unconditional love and endless support. Thank you.

H.H. 


\section{CONTENTS}

Page

ACKNOWLEDGMENTS

TABLES

FIGURES

$\begin{array}{ll}\text { CHAPTER I: INTRODUCTION } & 1\end{array}$

CHAPTER II: LITERATURE REVIEW

$\begin{array}{ll}\text { Anatomy } & 4\end{array}$

Skin 4

$\begin{array}{ll}\text { Fascia } & 6\end{array}$

$\begin{array}{lr}\text { Muscle } & 8\end{array}$

$\begin{array}{ll}\text { Bone } & 10\end{array}$

$\begin{array}{ll}\text { Vasculature } & 12\end{array}$

Non-Specific Neck Pain $\quad 13$

$\begin{array}{ll}\text { Definition } & 13\end{array}$

$\begin{array}{ll}\text { Causes } & 14\end{array}$

$\begin{array}{ll}\text { Current Treatments } & 15\end{array}$

$\begin{array}{ll}\text { Instrument Assisted Soft Tissue Mobilization } & 17\end{array}$

$\begin{array}{ll}\text { Definitions } & 17\end{array}$

$\begin{array}{ll}\text { Benefits } & 17\end{array}$

$\begin{array}{ll}\text { Graston Technique } & 18\end{array}$

$\begin{array}{ll}\text { Background } & 18\end{array}$

$\begin{array}{ll}\text { Theories } & 19\end{array}$ 
$\begin{array}{ll}\text { Benefits } & 20\end{array}$

$\begin{array}{ll}\text { Side Effects } & 21\end{array}$

$\begin{array}{ll}\text { Near Infrared Spectroscopy } & 21\end{array}$

$\begin{array}{ll}\text { Background } & 21\end{array}$

$\begin{array}{ll}\text { Benefits } & 22\end{array}$

$\begin{array}{ll}\text { CHAPTER III: METHODS } & 24\end{array}$

$\begin{array}{ll}\text { Study Design } & 24\end{array}$

$\begin{array}{ll}\text { Participants } & 24\end{array}$

$\begin{array}{ll}\text { Instrumentation } & 25\end{array}$

$\begin{array}{ll}\text { Intervention } & 26\end{array}$

GT Group $\quad 26$

$\begin{array}{ll}\text { IASTM Group } & 28\end{array}$

Control Group $\quad 29$

$\begin{array}{lr}\text { Procedures } & 29\end{array}$

$\begin{array}{ll}\text { Data Analysis } & 30\end{array}$

CHAPTER IV: RESULTS

CHAPTER V: DISCUSSION

$\begin{array}{ll}\text { Limitations } & 35\end{array}$

$\begin{array}{ll}\text { Conclusion } & 36\end{array}$

$\begin{array}{ll}\text { WORKS CITED } & 37\end{array}$ 


\section{TABLES}

Table

Page

1. Participant Demographics

2. Hemodynamics Change Scores Immediate Post - Baseline

3. ROM (cm) and PPT (kg) Scores 


\section{FIGURES}

Figure $\quad$ Page

1. GT Instrument Application 27

2. Lateral Flexion Stretch 28

3. Strengthening Exercises 28

4. IASTM Sham Application 29 


\section{CHAPTER I: INTRODUCTION}

The upper trapezius muscle is involved in many actions performed by the human body during everyday activities. It helps to stabilize and support the scapula when the arm is in an elevated position and keep the head in a neutral position for proper posture.1 Previous studies have shown the upper trapezius muscle is activated for sustained periods during daily activities, such as sitting at a desk or looking at a cellphone.1-4 Furthermore, the activities of daily living can affect the neck and shoulder musculature leading to changes in posture, such as Forward Head and Rounded Shoulders (FHRS).1,3,5

When the body is positioned in FHRS, the upper trapezius muscle activity is heightened, which leads to muscular imbalances.2,3 These muscular imbalances often result in upper trapezius muscle tightness, trigger points, dysfunctional movement, and neck pain. There have been several studies that reported sustained upper trapezius muscle activity is related to the development and presence of neck pain.2,4-7 Periods of sustained muscle activity create the spasm-pain-spasm cycle due to decreased blood flow, oxygen, and nutrient supply to the muscle.5,8-12 Furthermore, the formation of myofascial trigger points results in pain, limited range of motion, and restricted functional movements. A previous study defines a myofascial trigger point as a hyperirritable point found within a taut band of skeletal muscle that becomes painful with compression, stretch, or stimulation that causes distant referred pain from the specific point.14 Trigger points can be categorized as active or latent, where active trigger points are those causing consistent local and referred pain patterns and latent trigger points, although hyperirritable, do not cause pain until palpated.5,9,10,13 Active and latent trigger points present in the upper trapezius muscles can play an important role in mechanical neck pain.9,14 Non-specific neck pain (NS-NP), one of the top five leading chronic pain conditions, can be defined as 
mechanical neck pain without an identifiable diagnosis.1,15-20 Patients experiencing NS-NP can result from varying causes such as poor posture, occupational stressors, and myofascial trigger points.2,5,6,20-22

In the past, trigger points in the upper trapezius muscle were treated using many different manual therapy techniques. Significant improvements on pain pressure threshold (PPT) and cervical spine range of motion (ROM) using cervical mobilizations and ischemic compression techniques have been found.23 Concurrently, advanced manual therapy techniques like active release technique and muscle energy technique have proven to increase cervical ROM, decrease pain, and decrease the thickness of the upper trapezius muscle.5 However, a manual therapy technique that is lacking research for the treatment of the upper trapezius muscle is the use of instrument assisted soft tissue mobilization (IASTM).

A manual therapy technique, IASTM uses instruments for the evaluation of soft tissue with the goal of enhancing myofascial mobility.24-28 The physiologic effects on restricted tissue produced by IASTM have been well studied.24,27,29-33 IASTM enhances proliferation of extracellular matrix fibroblasts, improves ion transportation, decreases cell matrix adhesions, and decreases tissue viscosity.24-27,29,30 A type of IASTM, Graston Technique ${ }^{\circledR}(\mathrm{GT})$, uses stainless steel instruments that act similar to tuning forks by sending vibrations felt by the clinician to locate abnormal tissue properties.25,26,31,34 GT goes beyond typical IASTM by adding stretching, strength exercises, and cryotherapy to its procedural protocol.31 Additional benefits of GT include the perfusion of oxygen, nutrients, and blood and lymph flow to the treated area.31 The available research that has studied the effects of GT on the upper trapezius have found improvements in pain pressure threshold and increased range of motion.24,29 However, there is a need for further explanation of the effects of GT on the upper trapezius muscle hemodynamics. 
The presence of active trigger points, a result of decreased oxygen, found in the upper trapezius muscle may be a large contributor to neck pain and limited range of motion as a result of decreased blood flow.9,14,35 Therefore, the purpose of this research study was to measure active cervical ROM, neck pain, and subcutaneous hemodynamics of the upper trapezius following a single intervention of GT in patients with neck pain stemming from trigger points. We hypothesized that the GT treatment would cause immediate improvements on cervical ROM and neck pain and increase oxygenated hemoglobin to the upper trapezius muscle more than a sham treatment. 


\section{CHAPTER II: LITERATURE REVIEW}

\section{Anatomy}

\section{Skin}

The largest organ of the body is skin, the integumentary system, which covers the entire body varying in thickness.36-39 The skin is an organized, complex structure that functions to protect the body, regulate body temperature, sensory reception, aid metabolic functions, blood reservoir, and excretion.39 The skin consists of three layers named the epidermis, dermis, and hypodermis.36,39,40 The superficial layer, the epidermis, is made up of four to five layers of epithelial cells about 75 - 150 micrometers thick to act as a protective shield for the body.36,39,41 The layers of the epidermis from deep to superficial are as follows: stratum basale, stratum spinosum, stratum granulosum, stratum lucidum, and stratum corneum.36,39 Underlying the epidermal layer, the second layer of skin known as the dermis is approximately $1.5-2.5$ millimeters thick.36,42 There are two layers of the dermis, which are the papillary and reticular layers. 39 The interrelated networks of the dermis act as the main load-bearing component in skin and is stiffer than the epidermis.36,38 Lastly, the hypodermis as the third layer is not technically part of skin but has similar protective functions of shock absorption and insulation.36,37,39 This layer has varying thickness throughout the body and anchors the skin to underlying tissues such as muscles. $36,39,40,43$

The skin is comprised of a complex variety of contents that differ in each layer to serve their specific functions. The epidermis consists of five types of cells: epithelial cells, keratinocytes, melanocytes, dendritic cells, and tactile cells.39 The dermis consists of a vast community of cells, fibers, and tissues that makes up the tough, leathery layer. Dense irregular connective tissue creates the dermal layer and within consists collagen, elastin, ground 
substance, reticular fibers, and extracellular matrix.36,38,39,44,45 The dense irregular connective tissue is comprised of thick bundles of collagen fibers that provide high tensile strength and resiliency to skin. $36,38,39,46-48$ Elastin fibers allow the skin to undergo deformation and recoil back to its original shape and size.36,38,39,46-48 Ground substance, comprised of proteoglycans, lies between collagen and elastin fibers to act as a lubricant and an aid for collagen fiber formation. 38,47 The reticular fibers found in dense irregular connective tissue form elaborate branches around blood vessels and capillaries to support the tissue. 39 The extracellular matrix contains adipose cells and interlacing collagen fibers that run parallel with the skins surface. 39 The hypodermis consists of mostly adipose tissue to provide protection to underlying tissues.39

The contents of the skin layers work together to create the properties of skin. Previous research has established the properties of skin to be as follows: stress-strain, creep, elasticity, extensibility, viscoelasticity, anisotropy, and hysteresis.36,38,40,46,49,50 The external forces applied to skin, known as stressors, can cause the tissue to change in length or deform, placing the skin on strain. 38,49 Elastin fibers dictate the recoiling mechanism after deformation of the skin.36,40,46 Creep is simply the act of slowing deformation under stress by increasing the strain with straightened collagen fibers.38,50 Elastin provides the elasticity property of skin by allowing the material to return to its original shape when forces are removed. 38 The extensibility of skin is the maximum strain that can be placed on the skin before permanent deformation occurs. 38 Viscoelasticity is the concept where skin deformation is temporary under short-term stresses, but permanent deformation occurs with sustained stress. 38 The skin has varying thickness, patterns, friction lines, and other differences that can classify the skin as anisotropic. 38,49 Due to properties such as viscoelasticity, the skin may go through hysteresis where a change in the skin caused by forces may not reverse such changes in the same amount when the force is removed. 38 
Collectively, the properties of the skin are due to the variety of components that make up the different layers of the skin.

Fascia

According to the American Heritage Stedman's Medical Dictionary, fascia is considered a sheet or band of fibrous connective tissue that envelops, separates, or binds together muscle, organs, and other soft tissue structures throughout the body.51,52 Previous research has established fascia creates a continuous, tensegrity-like system throughout the entire body to provide body-wide links.52-58 As fascia can be found throughout the body, the characteristics, thickness, contents, and adherence to muscle may differ depending on location.53,59-61 Fascia is commonly thought to be made up of dense regular connective tissue with closely packed collagen fibers, elastin fibers, and hyaluronic acid.31,39,62-64 These contents work to provide tension, flexibility, and gliding properties to fascial tissue.31,39,62-64 According to Stecco et al.52, between the skin and muscle there are three fascial layers which are the superficial fascia, deep fascia, and epimysium that all contribute to the characteristics of the tissue.

The first layer, superficial fascia, separates the skin from the musculoskeletal system to allow proper sliding between them.31,52,62,63 The superficial fascia can be identified throughout the body as thicker in the lower extremities and posterior aspect.31,52,61-63 Found within the superficial fascia are many free nerve endings, nociceptive fibers, adipose tissue, collagen fibers, and elastin fibers.31,39,62,63 The superficial fascia adheres to the deep fascia on bony prominences and ligamentous folds.52 The deep fascial layer is a well-organized, dense, fibrous membrane that forms an elaborate network which surrounds and separates muscles, forms sheaths for nerves and vessels, strengthens ligaments, and binds structures together.31,52,62,63 Deep fascia consists of dense irregular connective tissue, free nerve endings like Ruffini and Pacini corpuscles, and 
aponeurotic fascial tissue.31,52,62,63,65,66 Lastly, the epimysial fascia, which is an extension of the deep fascia, tightly covers the muscles of the trunk.31,62,63

Previous studies provide important information on the roles and properties of fascia due to their contents and rich innervation. The most well-known role of fascia is the connection of muscle to the body.32,53,67,68 In recent studies, the contractile cells, free nerve endings, mechanoreceptors, and nociceptors found in fascia allow for proprioceptive and nociceptive function.31,53,59,62,63,69-75 These studies relate these roles to the etiology of musculoskeletal pain of the connected anatomical structures.53,55,56 Other widely accepted roles of fascia include: aiding venous return, interactions among limb muscles, movement perception and coordination, protective sheets for underlying structures, support for subcutaneous structures, and integrity of skin. $52,60,76-86$

The literature suggests two main properties of fascia: stiffness and force transmission. Wilke et al.32 described fascial stiffness as the resistance to external deformation by cellular contraction and fluid modification. When a mechanical stimulus is applied to fascia, the tissue responds with a "strain-hardening" effect with an initial decrease in stiffness and recovery of stiffness at rest.32,87,88 Changes in water content influence the viscoelastic behavior of connective tissue thus manipulating fascial stiffness.32,89-91 The stiffness of fascia offers the ability of force created by muscles to be transmitted through the tissue.33,52,53,68,92-95 An estimated 30-40\% of force generated by muscle is transmitted through the fascial tissues surrounding the muscle.31,52,62,63,96 The myofascial transmission may act as protection to avoid overloading muscles but can contribute to musculoskeletal pain conditions. 32,54 


\section{Muscle}

Muscles have the ability to transform chemical energy, adenosine triphosphate (ATP), into directed mechanical energy and produce force. 39 There are three types of muscle tissue: smooth, cardiac, and skeletal muscle.39 Smooth muscle tissue is found in the walls of hollow visceral organs, stomach, urinary bladder, and respiratory passages and forces fluids and other substances through internal body channels. 39 Cardiac muscle tissue is found only in the heart which causes the rhythmic movement of blood throughout the body.39 Skeletal muscle tissue is the most abundant muscle tissue found throughout the body as it creates the muscles of the body.39

Skeletal muscle cells can be distinguished by their elongated and striated appearance connective tissue sheaths, and voluntary control.39 Also known as muscle fibers, skeletal muscle tissue is the only muscle type subject to the conscious control of the somatic nervous system as every muscle fiber is supplied with a nerve ending. 39 The three connective tissue sheaths: epimysium, perimysium, and endomysium provide continuous connections of the muscle itself and tendons that attach muscles to bone.39 Typically, each muscle is served by one nerve, one artery, and one or more veins that enter or exit near the center of the muscle and branch through its connective tissue sheaths.39 The functions of muscle include: movement production, posture and body position support, joint stabilization, and heat generation.39 Properties of muscle tissue such as, excitability, contractility, extensibility, and elasticity set this tissue apart from the others. Excitability is defined as the ability of a cell to receive and respond to a stimulus by changing its membrane potential.39 For example, neurotransmitters are released by nerves serving the muscle and elicit a response of the cell. Contractility, the ability to shorten forcibly when stimulated, can be the response of the cell to the neurotransmitter. Muscle contraction is possible as each muscle 
is served by at least one motor nerve, which contains axons of numerous motor neurons that transmit action potentials through neuromuscular junctions.28 As muscle contraction occurs the muscle cells shorten but they also have the ability to be stretched beyond their resting length when the skeletal muscle is relaxed, known as extensibility.39 Also, the elasticity property of muscle cells allows the muscle to recoil and resume its resting length. 39

The cervical musculature plays an important role in normal mobility and stability of the cervical spine. 97 The prime cervical flexor muscles include: sternocleidomastoid, anterior scalene, middle scalene, and posterior scalene. The sternocleidomastoid (SCM) muscle originates on the manubrium of the sternum and the medial one-third of the clavicle and inserts at the mastoid process and the lateral portion of the superior nuchal line of the occipital bone.39,98 This muscle is innervated by the accessory nerve, or cranial nerve XI, and cervical spinal nerves C1 through C3.98 The SCM bilaterally performs elevation of the rib cage and cervical flexion; whereas, unilaterally it rotates the cervical spine to the opposite side and laterally flexes the cervical spine to the same side.39,98 The scalene muscles include three portions: anterior, middle, and posterior. All three perform the same actions of bilateral cervical flexion and elevation of the ribs during inhalation and unilateral cervical rotation to the opposite side and laterally flexing the cervical spine to the same side. 98 The anterior scalene originates from the transverse processes of C3 through C6, inserts at the first rib, and is innervated by cervical nerves C3 through C8.39,98 The middle scalene has its origin on the transverse processes of $\mathrm{C} 2$ through $\mathrm{C} 7$ and its insertion at the first rib.39,98 This muscle is innervated by cervical spinal nerves C3 through C8.98 The posterior scalene originates from the transverse processes of $\mathrm{C} 6$ and $\mathrm{C} 7$ with its insertion on the second rib.39,98 It is also innervated by cervical nerves C3 through C8.98 The prime cervical extensor muscles include: splenius capitis, splenius cervicis, levator scapulae, and upper 
trapezius. The splenius capitis has its origin on the inferior half of the ligamentum nuchae and the spinous processes of $\mathrm{C} 7$ through $\mathrm{T} 4$ with its insertion on the mastoid process, lateral portion of the superior nuchal line, and the occipital bone.39,98 It is innervated by the cervical spinal nerves $\mathrm{C} 1$ through $\mathrm{C} 8.98$ This muscle acts to bilaterally extend the cervical spine and unilaterally rotate and laterally flex the cervical spine to the same side.39,98 The splenius cervicis muscle originates at the spinous processes of $\mathrm{T} 3$ through $\mathrm{T} 6$, inserts at the transverse processes of C1through C3, and innervated by the cervical nerves C1 through C8.39,98 Bilaterally, this muscle causes cervical extension; whereas, unilaterally it causes cervical rotation and lateral flexion to the same side.39,98 The levator scapulae originates from the transverse processes of $\mathrm{C} 1$ though $\mathrm{C} 4$ and inserts at the medial border of the scapula between the superior angle and the superior portion of the spine of the scapula.39,98 This muscle is innervated by cervical nerves C 3 through C5 and the dorsal scapular nerve.98 It acts to bilaterally extend the cervical spine and unilaterally elevate the scapula, downwardly rotate the scapula, laterally flex and rotate the cervical spine to the same side. 39,98 The upper trapezius muscle has its origin at the external occipital protuberance, medial portion of the superior nuchal line, ligamentum nuchae, and the spinous processes of C7.39,98 This muscle inserts at the lateral third of the clavicle, the acromion process, and the spine of the scapula and is innervated by the accessory nerve, or cranial nerve XI, and cervical spinal nerves C3 and C4.39,98 Bilaterally, it performs cervical extension, and unilaterally performs upward rotation of the scapula, cervical rotation to the opposite side, and cervical lateral flexion to the same side. 39,98

Bone

All bones perform seven important functions including: support, protection, anchorage, mineral and growth factor storage, blood cell formation, triglyceride fat storage, and hormone 
production. 39 The bones of the cervical spine work to support the head and provide attachment sites for muscles that move the neck. The cervical spine consists of seven vertebrae of different shapes and sizes that allow versatile movement while being the most mobile and least stable part of the spine.15,99 Although the cervical vertebrae are different shapes and sizes, they possess a concave posteriorly curvature and are the smallest and lightest vertebrae in the spine. 39,98 The first two cervical vertebrae, $\mathrm{C} 1$ and $\mathrm{C} 2$, also known as the atlas and axis, can be differentiated from the remaining cervical vertebrae by their robust shape, absence of an intervertebral disc, and uniquely modified structures.39 The atlas (C1) does not contain a body or spinous processes but is rather a ring of bone that consists of anterior and posterior arches and lateral masses that serve as articular facets.39,98 The superior articular facets articulate with the occipital condyles, while the inferior articular facets form joints with the axis (C2) to allow flexion and extension motions at the cervical spine. 39 The axis does possess a vertebral body, spinous processes, and transverse processes but contains an unusual feature that projects posteriorly from the body, the dens.39,98 The dens acts as the missing body of the atlas and fuses the two vertebrae to provide a pivot for rotation of the cervical spine. 39 The remaining cervical vertebrae C3 through C7 possess distinguishing features including: an oval shaped vertebral body, a short spinous processes that projects posteriorly and is bifid at its tip, a large, triangular shaped vertebral foramen, and a transverse foramen in each transverse processes to allow vertebral arteries to pass through to the brain. 39 The last cervical vertebrae, C7, does not have a bifid spinous process and is much larger than the other cervical vertebrae, which acts as a palpable bony landmark. 39,98 The cervical spine region between $\mathrm{C} 3$ and $\mathrm{C} 7$ has the greatest range of motion of the entire spine with cervical movements of flexion, extension, lateral flexion, and rotation. 39 Other bony landmarks that influence movement at the cervical spine include the thoracic vertebrae, lateral one-third of 
the clavicle, the acromion process, and the scapula as they act as bony attachment sites for muscles. 39,98

\section{Vasculature}

Vasculature refers to the supply of blood to specific regions of the body.39 Concerning the skin, blood flow through the skin helps to supply nutrients to the cells which aids the regulation of body temperature and provides a blood reservoir for the body.39 The epidermal layer is avascular, meaning no blood reaches the cells of this region, but is innervated by fibers and nourished by the substances that are diffused from blood vessels into the underlying connective tissue and dermal layer.39 The dermal layer of skin has an extensive vascular supply and can hold up to 5\% of the body's entire blood volume.39 However, when the muscles need greater blood supply, the nervous system constricts the dermal blood vessels to push more blood into circulation allowing blood to be more available to the muscles.39 The underlying fascial layers are supported by arteries, veins, and lymphatic vessels.31,39,62,63

The skeletal muscles have a rich blood supply with muscle capillaries being the smallest of the body's blood vessels that stretch long and wing to create numerous cross-links that accommodate changes in muscle length.39 Due to the contracting muscle fibers, large amounts of energy are required to supply continuous oxygen and nutrients via the arteries.39 Although blood flow in skeletal muscle varies with fiber type and muscle activity, resting muscles receive about one liter of blood per minute with only about $25 \%$ of their capillaries open. 39 On the other hand, when muscles are physically active the sympathetic nervous system causes vasoconstriction of vessels of the digestive system and skin to increase blood flow in direct proportion to the greater metabolic activity as all capillaries of the active muscles are opened.39 


\section{Non-Specific Neck Pain}

\section{Definition}

Neck pain is a common musculoskeletal disorder that can cause varying levels of disability and is considered one of the top five leading chronic pain conditions.1,15-20,100,101 There is a high prevalence of neck pain among occupational sectors, middle aged people, and women.1,15,18 Previous research has estimated about two-thirds of people will experience neck pain at some point in their lives.6,15,16,18,20,101,102 The prevalence of neck pain being so high imposes considerable personal and socioeconomic burden on those individuals affected by this musculoskeletal disorder.17,20,103-105

Each individual may experience different neck pain symptoms, so the term nonspecific neck pain (NS-NP) has been established to group individuals with neck pain. NS-NP is used as a classification for patients experiencing neck pain without an identifiable disease, abnormal anatomical structure, or specific cause.17,20 This pain disorder is typically diagnosed on clinical grounds alone when there are no red flag features to suggest more serious conditions.15,97,106 Previous studies on NS-NP define the condition as neck pain with a mechanical or postural basis, which includes pain following whiplash injury without bony or neurological injury but does not include fibromyalgia pain.15-17,107 Binder et al.15 stated that NS-NP typically resolves within days or weeks, but can reoccur and become chronic. Symptoms associated with NS-NP often occur in combination with limited movement and poorly defined neurological symptoms affecting the upper limbs.16 Typical signs and symptoms include: sensitivity, fatigue, stiffness of neck and shoulder muscles, radiating pain to the occiput, neck, shoulders, and upper limbs, weakness, headache, and limited cervical range of motion.15-17,108,109 


\section{Causes}

As mentioned, there is no specific, identifiable underlying cause of NS-NP but previous literature has identified risk factors, postural basis, mechanical basis, and soft tissue involvement that can be related to the disorder. Generally accepted risk factors that may predispose an individual to neck pain include poor posture, anxiety and depression, neck strain, occupational or sporting activities, genetics, sleep problems, obesity, sedentary lifestyle, trauma, back pain, and general poor health.15,16,20,110-113 Although there is an understanding of the risk factors that contribute to NS-NP, each individual presents differently as the cause is multifactorial.15

Poor posture can be defined as an increased forward head, increased thoracic kyphosis, and a more anterior shoulder position.7 Occupations such as computer workers, manual laborers, healthcare workers, and drivers are specifically prone to this poor posture that can lead to an imbalance in muscular pattern, reduce epidemiological function of the body, and weakens soft tissues.2,5,20,21 Previous studies have associated sustained awkward postures with a long-term low intensity stimulus and activity of the upper trapezius, a prime cervical muscle.3-5 Concurrently, Nicoletti et al.6 reported sustained upper trapezius muscle activity directly correlates with the presence and may predict the development of neck pain.

Previous literature suggests that weakness or fatigue of neck muscles, specifically the deep cervical flexors and deep extensors of the cervical spine, are related to neck pain as about $80 \%$ of spinal stability is based on muscular activity.97,114-119 The reduced muscle activity, such as in the upper trapezius, leads to the spasm-pain-spasm cycle which decreases blood, oxygen, and nutrient supply to the muscle further leads to the formation of myofascial trigger points.5 Chiarotto et al.22 found the prevalence of active trigger points ranged from $14.8 \%$ in the levator scapulae to $38.5 \%$ in the upper trapezius muscles in people with neck pain.20 Other previous 
studies found a relationship between decreased myoelectric activity of trigger points with muscle weakness and increased myoelectric activity of trigger points with muscle stiffness, spasms, and irritable muscles.20,120-122 The fascia connecting muscles may also be affected and lead to myofascial pain, a common cause of neck pain.20,123 Myofascial pain involves discrete and diffuse areas of sensitivity within one or more muscles as a result of sustained muscle contractions, local ischemia, and muscle fiber shortening.20,123 Overall, soft tissue injury is considered the most likely mechanical explanation for NS-NP symptoms. 15

\section{Current Treatments}

As NS-NP does not have a clear cause, the treatment plan is often based on the clinical findings of an evaluation by a clinician.97,119 Although there is still no consensus on the best form of treatment for NS-NP, previous studies found improvement using a combination of treatment types.11,15,17,20 The goal of treatment should include correcting any underlying structural and postural imbalances.11,20 Among the evidence for treatments, therapeutic exercise has the strongest evidence when combined with manual therapy, while alternative treatments and medication do not have as strong of evidence but are still accepted.15,17,20,124-133

Manual therapy treatment of NS-NP includes massage, mobilizations, manipulations, stretching, myofascial release therapy, and dry needling techniques.5,15,17,20 Previous studies have found great improvements on NS-NP using techniques such as these. Myofascial release therapies such as, active release technique, muscle energy technique, strain-counter strain, and ischemic compression, have been proven to decrease neck pain, increase cervical range of motion, improve pain pressure threshold, and improve neck disability index scores.5,23,134,135 Simple manual therapy techniques like stretching and massaging have been found to improve cervical range of motion and pain pressure threshold in patients with NS-NP.136,137 On the other 
hand, a less common form of manual therapy, dry needling, has been recommended in the treatment of neck pain as it can improve pain pressure threshold, improve neck disability index scores, and decrease pain. $134,135,138$ Cervical manipulations and mobilizations have limited evidence but have proven effective in reducing pain, improving range of motion, and improving pain pressure threshold in comparison to other treatment options.15,16,23,100,130,131,136,139-143

Therapeutic exercise is the basis for most treatment plans of people experiencing NS-NP because of the emphasis on reestablishing cervical muscle functions.17 Binder et al.15 established the implementation of exercise programs is more effective than usual care of neck pain. 100,127,128,144-146 The use of exercise strengthening programs alone in the treatment of NS-NP can reduce pain but has been found more effective when in combination with manual therapies like, manipulations and mobilizations. 15 Cohen et al.20 stated that therapeutic exercise can be beneficial for neck pain by stimulating endorphin secretion, which can help to improve sleep, mood, and prevent deconditioning of muscles.

Alternative treatments include a vast variety of non-traditional approaches to musculoskeletal disorders. The range of treatment types include acupuncture, cupping, yoga, meditation, and stress management.15,20,147-149 Previous studies found after a session of acupuncture, patients with NS-NP experience a decrease in pain and improve their quality of life.16,17 Although the therapeutic effects of treatments such as yoga, stress management, and meditation have not been thoroughly assessed, they have been shown to aid in the improvement of neck posture. 15

Medications such as, non-steroidal anti-inflammatory drugs (NSAID), analgesics, muscle relaxants, and anti-depressants are commonly used to treat NS-NP.16 Hsieh et al.150 and Predel et al.151 established benefits of using a topical NSAID in people with neck pain, which is consistent 
with more recent literature stating the efficacy of topical NSAIDs.20,152 Although the use of analgesics, NSAIDs, and antidepressants are used empirically in the treatment of NS-NP, there is still not strong enough evidence to determine their efficacy.16

\section{Instrument Assisted Soft Tissue Mobilization}

\section{Definition}

Instrument assisted soft tissue mobilization (IASTM) is a technique used to treat musculoskeletal pathologies by mobilizing the injured soft tissue using different instruments.27,31,63,153-155 There are different forms of IASTM including: gua sha, Graston Technique ${ }^{\circledR}$, sound-assisted instrumentation, and fascial abrasion.27,153,155-157 IASTM is used to help remove scar tissue and promotes soft tissue to return to its normal functions.27,158-160 This is achieved by scraping the skin with an instrument to bring blood flow and oxygen to the underlying tissues to facilitate the healing process.27,156,161 The use of IASTM on soft tissue works to inhibit tissue restrictions by stimulating the repair and realignment of collagen, an extracellular matrix protein.19,20,23,25,26,156,158,162-164 The fibroblasts found in the extracellular matrix have been shown to increase in number after the use of IASTM, which aids connective tissue remodeling.24,26,27,29-31,63,158,162-164 Additionally, IASTM restores the natural gliding and proper lubrication between tissue layers.27,31 Previous studies have justified the use of IASTM for pathologies such as: chronic fibrosis, lateral epicondylitis, carpal tunnel syndrome, trigger thumb, plantar fasciitis, patellar tendonitis, achilles tendonitis, and lumbar

pain. $25,28,29,154,159,160,165-170$

\section{Benefits}

Implementing IASTM as a treatment for soft tissue pathologies is simple, practical, and provides benefits to the clinician, patient, and musculoskeletal pathology.27,171 For the clinician, 
using IASTM allows for better detection of altered tissue with a mechanical advantage from the instrument.26 The vibrations felt through the instruments being used alert the clinician of tissue changes while allowing deeper penetration and more specific treatment to the tissue.26 IASTM treatment time is much shorter when compared to a traditional friction massage, which benefits the clinician and patient.27 Additionally, the use of IASTM in treatment has been shown to decrease overall rehabilitation time and return the patient back to physical activities faster.27 This can be achieved as IASTM has been found efficient in reducing pain, improving range of motion, and improving function.26,27,172,173

\section{Graston Technique}

\section{Background}

Graston technique ${ }^{\circledR}$ therapy (GT), a form of IASTM, was created in 1994 by clinical personnel and university researchers to create a more efficient manual therapy application.31 The researchers designed GT to give clinical practitioners a unique alternative modality for the benefit of patients.31 This evidence-based form of IASTM incorporates six specially designed stainless-steel instruments with beveled edges to enhance the clinician's ability to detect and treat soft tissue dysfunctions.25,31 GT generates mechanical micro-traumatic damage to the area being treated to create an inflammatory response that accelerates the healing process and restores more flexible tissue.30 The promotion of proper fiber alignment can only be achieved if the GT treatment is combined with stretching and rehabilitative strengthening exercises. 31 Although this technique is a type of IASTM, it can be distinguished by its registered trademarks and protocol for use.31 The creators of GT ensure that only clinicians who have been trained by an authorized Graston Technique, LLC certified instructor using Graston technique brand instruments can represent themselves as performing Graston technique therapy.31 
The GT protocol for treatment includes the following components: examination, warmup, IASTM treatment strokes, post-treatment stretching, strengthening, and possibly cryotherapy.26,31 The Graston technique brand instruments must be used as they help to locate remote myofascial strain patterns and amplify the tactile feel of soft tissue restrictions. 31 Instruments are applied to the skin in multidirectional, unique strokes at a thirty-degree to sixtydegree angle to ensure the undulation of the instruments detect and treat soft tissue irregularities.24,29,162 A list of the clinical indications for the use of GT follows: tendinopathies, fascial syndromes, myofascial pain syndromes, ligament pain syndromes, edema reduction, scar tissue/adhesions, entrapment syndromes, and secondary soft tissue lesions associated with other diagnoses.31 Clinicians need to keep in mind the relative contraindications of GT like, burn scars, pregnancy, autoimmune disorders, diabetes, acute inflammation, skin conditions, and others. 31 However, if a patient presents with any of the following, it is an absolute contraindication for GT use: open wounds, unhealed suture sites, sutures, thrombophlebitis, uncontrolled hypertension, inflammatory conditions due to infection, unstable fractures, hypersensitivity/intolerance of GT, contagious or infectious skin conditions, hematoma, myositis ossificans, osteomyelitis, insect bite of unexplained origin. 31

\section{Theories}

Similar to IASTM, GT therapy has been purported to decrease cell matrix adhesions, remove tissue adhesions, release fascial restrictions, and break down cross-fiber links caused by soft tissue dysfunctions.24,29-31,162,174-187 By using the GT brand instruments to release these restrictions, motion is restored to fascia and muscle tissue.31,62,63 At the cellular level, previous studies have shown GT therapy can improve ion transport, enhance proliferation of fibroblasts, and promote collagen synthesis.24,29-31,62,63,162 The Graston Technique M1 Training Manual states 
the physiological effects of GT therapy are as follows: increased fibroblastic activity, enhanced blood perfusion, increased stem cells, Pizoelectric effect, Davis' law, altered neural activity, and mechanotransduction.31,171,188 Additionally, the increased tissue temperature caused by the friction of the instruments stimulates blood, nutrients, and lymph to rush to the treated area and increases circulation to enhance the healing process.29,31

\section{Benefits}

Previous research has shown the benefits of Graston technique therapy include aiding the clinician, patient rehabilitation, and treatment outcomes. The GT instruments provide a mechanical advantage for the clinician that allows less pressure and energy to be used while increasing the depth of treatable tissue.31 Promoters of GT claim the instruments do not compress tissue, so the superficial fascial layer is easily mobilized to make deeper restrictions more accessible.31,34 An additional benefit of the GT brand instruments is the variety of shapes and sizes of the six different instruments. The smaller edges found on specific GT instruments are able to separate fibers and outline anatomy in an effective manner.31 As GT therapy has proven to be immensely effective, the total treatment time decreases and returns the patient to function much faster than other forms of manual therapy.31 There are various levels of evidence that suggest GT reduces pain, improves range of motion, and improves overall function.26,172,173 Previous studies have found GT as an effective treatment for the following pathologies: lateral epicondylitis, carpal tunnel syndrome, hamstring tendinopathy, low back pain, plantar fasciitis, achilles tendinopathy, trigger finger, peroneal tendonitis, quadriceps tear, DeQuervain's tenosynovitis, chronic calf pain, and tibialis posterior strain.28,31,162,167,189-199 GT therapy not only aids the rehabilitation of specific pathologies but can also can be used to improve pain pressure 
threshold of trigger points, improve shoulder, lumbar spine, hip, and ankle range of motion, increase hamstring and iliotibial band flexibility, and improve grip strength.26,28-30,200-202

\section{Side Effects}

The principle of GT therapy is to enhance myofascial mobility with limited adverse effects, but patients may experience side effects if GT protocol is not followed correctly. For example, when GT therapy is applied in excess the patient's condition may exacerbate. 31

Clinicians using GT should avoid using too many treatment modalities, treating one specific restriction for too long, using GT therapy too long during a single session, and using excessive pressure.31 When GT is used incorrectly a patient may experience discomfort, petechia, bruising, or fear of GT treatment.26,31

\section{Near Infrared Spectroscopy}

\section{Background}

Near Infrared Spectroscopy (NIRS) was originally developed as a non-invasive method for investigating the oxygenation of brain tissue.203,204 Chance et al.205 first applied NIRS technology to study exercising skeletal muscle in humans in 1985.206 Today, NIRS is an evolving technology that allows a safe, non-invasive method to explore the characteristics of muscle tissue among others.207-209 Crenshaw et al.204 explains the principle of differential absorption properties of oxygenated and deoxygenated hemoglobin in the near-infrared range of the light spectrum to assess skeletal muscle oxygenation as the basis for NIRS technology. Previous studies established wavelengths between 600 to 900 nanometers is scattered and is absorbed by hemoglobin and provide an index for deoxygenation. 209,210 Near infrared light can propagate through tissues and is absorbed by the hemoglobin and myoglobin found in muscle, but the refracted light not absorbed is used to measure the relative changes in oxygen consumption and 
delivery within muscle tissue.203-205,209-212 A probe or NIRS device is placed onto the skin that enables the monitoring of signals from small vessels like arterioles, capillaries, and venules deep within the muscle.204 Sako et al.206 stated the parameters commonly measured by NIRS are as follows: oxyhemoglobin/myoglobin (Hb/MbO2), deoxyhemoglobin/ myoglobin (Hb/MbR), and total hemoglobin/myoglobin (THb/Mb). Previous studies have established NIR technology as a useful non-invasive method for monitoring muscle hemodynamics.210

\section{Benefits}

The major benefit of NIRS technology is the non-invasive application in clinical and research settings. A non-invasive method translates to a technique that can be applied to humans without discomfort or risk, repeatedly.210,213 Additionally, the NIRS devices are practical and easy to use while being inexpensive in comparison to other methods like magnetic resonance spectroscopy.208,209,213,214 Previous studies have established the efficacy, validity, reliability, and reproducibility of using the NIRS technology to monitor muscle hemodynamics.204,206,209,210,214,215 NIRS can measure various aspects of skeletal physiology of a resting muscle and exercising muscle.206,209,214,215 Mancini et al.210 and Hampson et al.216 confirmed NIRS measurements are not influenced by skin blood flow as skin temperature rises with maximal exercise. The aspects of skeletal muscle physiology that can be measured by NIRS includes oxidative metabolism, skeletal muscle blood flow, skeletal muscle oxygen consumption, and changes in muscle blood volume.204,206,209,214,215,217-221 In clinical and research settings, there is an increasing interest to use the NIRS method to study the hemodynamics of different skeletal muscles.208,209 Previous studies have used NIRS technology on the vastus lateralis, forearm muscles, gastrocnemius-soleus complex, and the upper trapezius.204,209,210,213,214,216,217,219-233 As 
NIRS technology continues to evolve, more muscles will be able to be monitored and more information on skeletal muscle hemodynamics will emerge. 


\section{CHAPTER III: METHODS}

\section{Study Design}

This was a single blinded, controlled laboratory research study with randomization, utilizing GT on active trigger points found in the upper trapezius muscle. The independent variables were treatment group (control, GT, or IASTM) and time (baseline, immediate postintervention, and 24 hours post-intervention). The dependent variables were neck ROM, PPT, and subcutaneous tissue hemodynamics (superficial and deep oxygenated, deoxygenated, and total hemoglobin). Hemodynamics were only measured at baseline and immediate postintervention

\section{Participants}

Sixty participants with self-reported neck pain volunteered to participate in this study (Table 1). Inclusion criteria was the presence of trigger points in the upper trapezius muscle and NS-NP experienced within the last three months. Exclusion criteria was previous history of a diagnosed neck injury, history of spinal or shoulder surgery, cancer, kidney dysfunction, pregnancy, taking an anticoagulant medication, varicose veins, polyneuropathies, diabetes, heart failure, contagious skin conditions, open wounds, thrombophlebitis, and hypertension. Participants were informed of the procedures, risks, and benefits of participating in this research study and signed an informed consent form prior to participation. This study was approved by the Institutional Review Board at Illinois State University. 
Table 1. Participant Demographics

\begin{tabular}{|c|c|c|c|c|c|}
\hline Variable & Age & Sex & Height $(\mathrm{cm})$ & Weight $(\mathrm{kg})$ & $\begin{array}{c}\text { Treatment } \\
\text { Side }\end{array}$ \\
\hline $\begin{array}{c}\text { GT } \\
\text { N=20 }\end{array}$ & $21.8 \pm 2.9$ & $\begin{array}{c}\text { Male }=10 \\
\text { Female }=10\end{array}$ & $172.6 \pm 12.9$ & $76.3 \pm 14.9$ & $\begin{array}{c}\text { Right }=14 \\
\text { Left }=6\end{array}$ \\
\hline $\begin{array}{c}\text { IASTM } \\
\text { Sham } \\
\text { N=20 }\end{array}$ & $20.7 \pm 1.6$ & $\begin{array}{c}\text { Male }=5 \\
\text { Female }=15\end{array}$ & $168.5 \pm 9.4$ & $73.1 \pm 16.4$ & $\begin{array}{c}\text { Right }=13 \\
\text { Left }=7\end{array}$ \\
\hline $\begin{array}{c}\text { Control } \\
\text { N=20 }\end{array}$ & $22.2 \pm 4.6$ & $\begin{array}{c}\text { Male }=6 \\
\text { Female }=14\end{array}$ & $168.7 \pm 9.4$ & $73.5 \pm 16.8$ & $\begin{array}{c}\text { Right }=13 \\
\text { Left }=7\end{array}$ \\
\hline
\end{tabular}

\section{Instrumentation}

The cervical spine ROM for lateral flexion was measured using a tape measure. Previous research established using a tape-measure for cervical ROM to have good to very good intrareliability and inter-reliability and possess excellent correlation to goniometry measurements.234-237

A pressure algometer (Lafayette Manual Muscle Test System ${ }^{\mathrm{TM}}$, Model 01163) was used to measure the pain pressure threshold (PPT) and sensitivity of a specific trigger point site. Previous research has established pressure algometry to be useful in the evaluation of pain, diagnosis, and management of trigger points present in the upper trapezius muscle.238-244 Concurrently, this method is a valid and reliable tool used in research studying myofascial adhesions and trigger points.239,245-249

The upper trapezius muscle hemodynamics were measured using Near-Infrared Spectroscopy (NIRS) (PortaMon ${ }^{\text {TM }}$ Artinis Medical Systems). NIRS was first used in a 1997 study to demonstrate its application on human skeletal muscle.203 Concentration changes were gathered at a sample rate of $10 \mathrm{~Hz}$ for 2 minutes. Light absorbance at $763 \mathrm{~nm}$ and $845 \mathrm{~nm}$ allowed for the calculation of superficial and deep hemodynamics utilizing the modified Lambert-Beer Law. Light transmitting optodes were located at 30, 35, and $40 \mathrm{~mm}$ from the 
receiver allowing for light penetration between 15 and 20mm.203-213,217,218,220,221 Values for oxygenated, deoxygenated, and total hemoglobin were reported in micromolar units $(\mu \mathrm{M})$. The use of continuous-wave NIRS devices to measure skeletal muscle hemodynamics has a vast amount of previous research that have established the reliability, validity, and reproducibility of the technique.204,206,209,210,213,214 Crenshaw et al.204 concluded NIRS to have high reliability and reproducibility when assessing day-to-day measurements of the upper trapezius muscle.

\section{Intervention}

\section{GT Group}

The GT intervention group followed the GT protocol by completing an examination of soft tissue, warm up, instrument treatment, passive stretching, and strengthening exercises.26,27,31 First, the investigator of this study who is a certified athletic trainer and GT certified, palpated all participants to locate trigger points present in the upper trapezius muscles. The most prominent (painful) trigger point, regardless if identified as a latent or active, was marked with an " $\mathrm{X}$ " to indicate the treatment side. Next, participants completed a ten-minute warm up using an arm bike. Following the warm-up, GT was used to treat the marked trigger point and surrounding tissues for a total of five minutes. Treatment included the use of GT instruments: GT1 and GT4 using different strokes. In order to prepare the participant's tissue, the clinician performed a GT sweeping stroke with light intensity using the GT1 instrument for one minute. Then, the tissue surrounding the trigger point was treated with GT4 using a fanning stroke for two minutes. Finally, the marked trigger points were treated with the knob of GT1 using a swivel stroke for two minutes (Figure 1). The implementation of these strokes were based on previous research that has established sweeping and fanning strokes increase circulation to the treated area and swivel strokes reduce tissue stiffness.24,29,31 The participant was seated in an upright position 
with the arms resting at the thighs while the instruments were applied using multi-directional strokes at a thirty to sixty-degree angle to enhance the physiologic effects.24,31,162
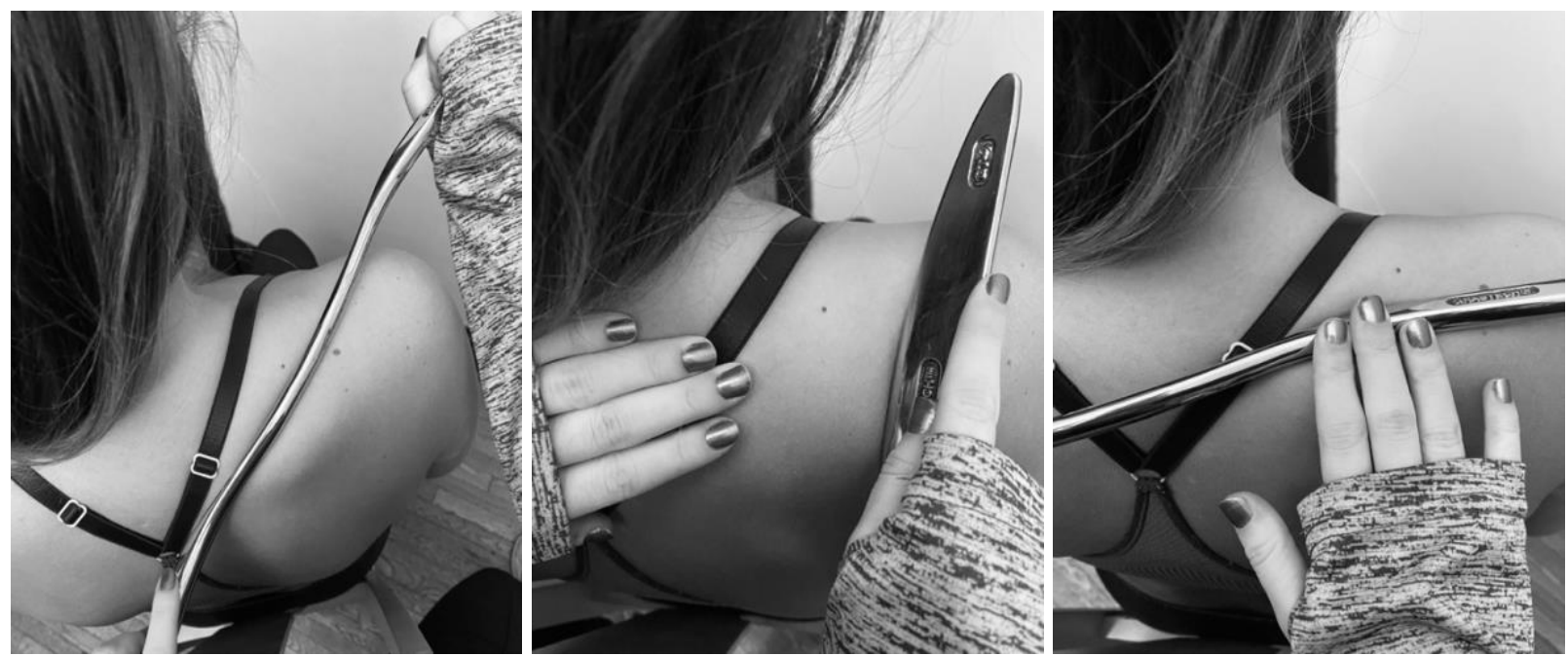

Figure 1. GT Instrument Application: GT strokes applied to the upper trapezius muscle in the following order: Sweep using GT1, Fan using GT4, and Swivel using GT1

Next, the clinician performed a passive stretch for lateral flexion contralateral to the treatment side (Figure 2). Lastly, the participants were instructed on how to properly perform the following strengthening exercises: shoulder shrugs, shoulder flexion, and shoulder press (Figure 3). These exercises were chosen because they are commonly referenced in rehabilitation literature for increased upper trapezius muscle activity.250-254 Schory et al.250 analyzed multiple studies to identify higher upper trapezius activity performed in a standing position. Shoulder shrugs were completed as the participant lifted both shoulders upwards towards the ears.251,252 The shoulder flexion exercise was performed with the forearms in a neutral position with the thumbs pointed up as the participant completed full active shoulder flexion ROM.250,253 The shoulder press exercise was completed with the participants starting with the elbow and shoulder flexed at ninety degrees followed by completing shoulder flexion ROM and elbow extension to raise the arms above the head.254 All three strengthening exercises were completed in three sets of six 
repetitions. Kim et al.27 explains that the inclusion of strengthening exercises after IASTM application enhances the realignment of collagen.

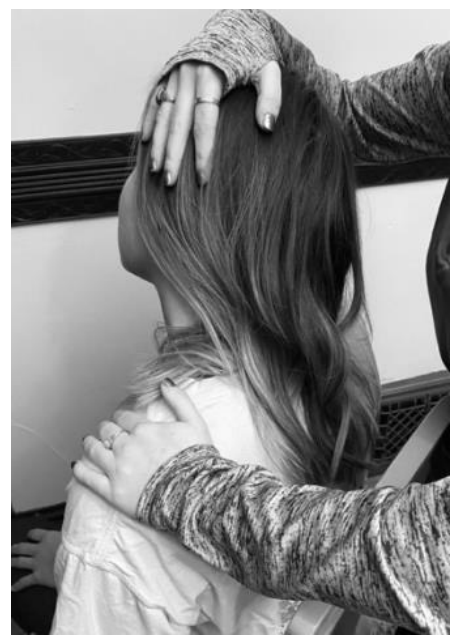

Figure 2. Lateral Flexion Stretch: Patient seated with arms relaxed as clinician stabilizes affected shoulder and laterally flexes the neck to the contralateral side.
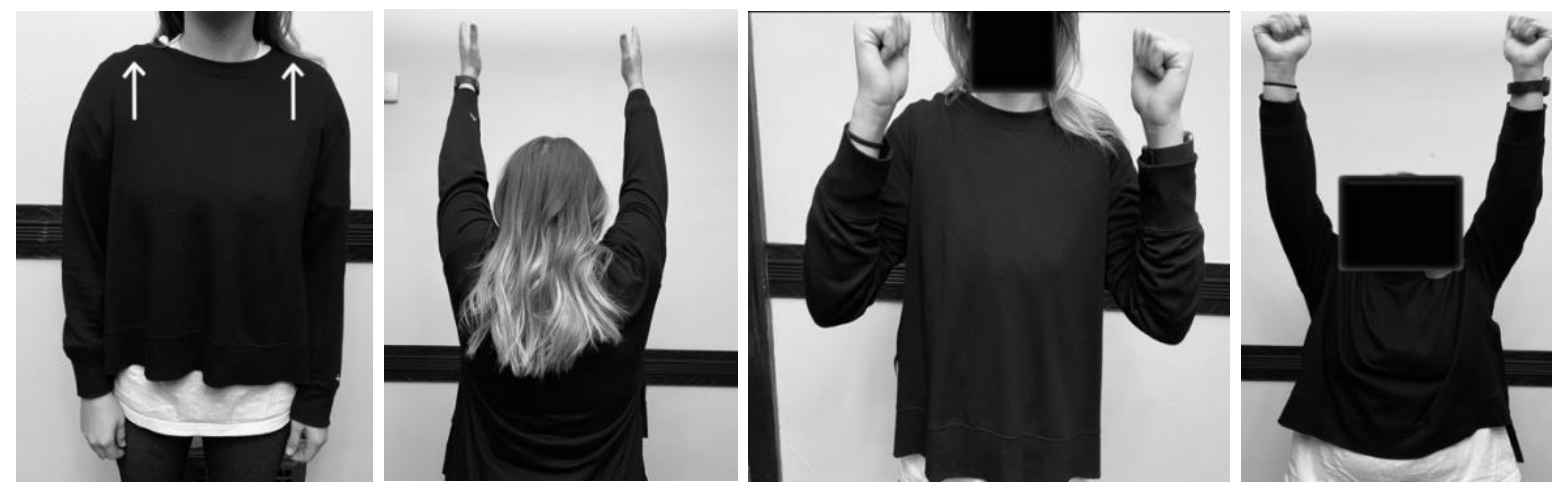

Figure 3. Strengthening Exercises: Participant completed shoulder shrugs, shoulder flexion (posterior view), and shoulder press (start to finish in anterior view), respectively.

\section{IASTM Group}

The IASTM intervention group completed the GT group protocol but received a different soft tissue mobilization tool as treatment to the upper trapezius trigger points. A generic IASTM tool (Fibroblaster ${ }^{\mathrm{TM}}$ ) was used as a sham treatment for the participants in this group. The participant was seated in an upright position with the arms resting on the thighs while the clinician applied a sweeping stroke to the suspected trigger points and surrounding tissue of the upper trapezius muscle for the allocated five-minute treatment time (Figure 4). After the 
application of IASTM treatment, the participants in this group received passive stretching and completed strengthening exercises.

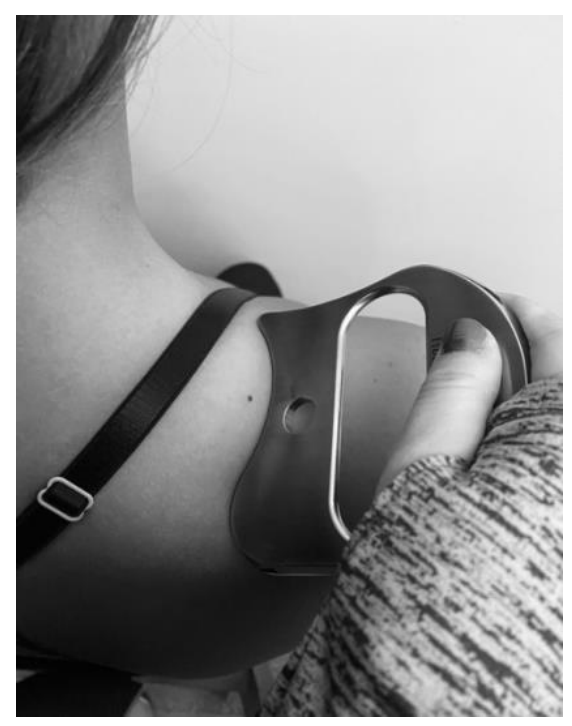

Figure 4. IASTM Sham Application: IASTM tool (Fibroblaster ${ }^{\mathrm{TM}}$ ) application on the upper trapezius muscle.

\section{Control Group}

The control group participants completed the GT protocol without the application of instrument treatment. After completing a warm-up, participants waited the allocated five-minute treatment time before concluding the protocol with passive stretching and strengthening exercises.

\section{Procedures}

All participants were randomly allocated into control, GT, or IASTM groups prior to the start of the intervention period. The participants, regardless of group assignment, followed the GT protocol including a ten-minute warm up, instrument treatment, passive stretching, and strengthening exercises.26,27,31 This sequence of events was followed by an immediate measurement of active cervical ROM, pain, and muscular hemodynamics of the upper trapezius.

Another clinician, blinded to group allocation and trained in how to perform the measurements, measured the dependent variables at pre-intervention and immediate post- 
intervention. Twenty-four hours post-intervention, the same clinician measured cervical ROM and pain. Cervical lateral flexion ROM was measured by a tape measure in centimeters from the earlobe to the acromion process and compared bilaterally. Pain was measured using the pressure algometer placed on the marked location of the most prominent trigger point found in the upper trapezius muscle for PPT. Measurement of PPT was performed three times and the average was recorded. The participant was seated upright on a chair with a backrest to support the thoracic spine and arms relaxed on the thighs for ROM and PPT measures. Subcutaneous hemodynamics were measured by a NIRS device placed parallel with the upper trapezius fibers around the site of the marked trigger point, secured with adhesive tape, and covered with a dark-colored cloth to restrict ambient light interference. The participant was prone on a treatment table with the arms relaxed by their side. All NIRS measurements were taken with the participant at rest with light intensity wavelengths at $800 \mathrm{~mm}$ for a total of two minutes.

\section{Data Analysis}

One participant from each group was removed from data analysis due to the NIRS device not recording any data. For hemodynamics, change scores were calculated by subtracting the baseline measure from the immediate post-intervention measure. Separate one-way ANOVAs were used to assess oxygenated, deoxygenated, and total hemoglobin at two depths across groups. For ROM and PPT, separate repeated measures ANCOVAs, with the baseline value as the covariate, were used to assess differences at immediate post and 24 hours post-intervention across groups. Alpha level was set a priori at $\mathrm{p} \leq 0.05$. Statistical analyses were performed using SPSS (IBM SPSS Statistics for Windows, version 25.0; IB < Corp, Armonk NY). 


\section{CHAPTER IV: RESULTS}

Regarding hemodynamics, there were significant differences between intervention groups with changes in superficial and deep oxygenated and total hemoglobin $(\mathrm{p} \leq 0.05)$. Post-hoc tests revealed that the GT and Sham interventions had increased levels compared to the control group $(\mathrm{p} \leq 0.008)$ indicating increased blood flow. There were no differences between GT and Sham $(\mathrm{p} \geq .555)$ (Table 2).

Table 2. Hemodynamics Change Scores Immediate Post - Baseline

\begin{tabular}{|c|c|c|c|c|c|c|}
\hline Variable & $\begin{array}{c}\text { Superficial } \\
\text { Oxygenated }\end{array}$ & $\begin{array}{c}\text { Superficial } \\
\text { Deoxygenated }\end{array}$ & $\begin{array}{c}\text { Superficial } \\
\text { Total } \\
\text { Hemoglobin }\end{array}$ & $\begin{array}{c}\text { Deep } \\
\text { Oxygenated }\end{array}$ & $\begin{array}{c}\text { Deep } \\
\text { Deoxygenated }\end{array}$ & $\begin{array}{c}\text { Deep Total } \\
\text { Hemoglobin }\end{array}$ \\
\hline GT & $19.5 \pm 13.5$ & $3.0 \pm 6.8$ & $22.5 \pm 18.9$ & $17.2 \pm 12.3$ & $1.7 \pm 6.2$ & $19.3 \pm 16.3$ \\
\hline Sham & $19.6 \pm 16.3$ & $3.1 \pm 6.8$ & $22.7 \pm 21.8$ & $19.8 \pm 13.8$ & $2.4 \pm 6.3$ & $22.1 \pm 17.5$ \\
\hline Control & $-1.5 \pm 14.2$ & $0.3 \pm 11.8$ & $-2.2 \pm 25.7$ & $-0.5 \pm 14.2$ & $1.0 \pm 13.1$ & $0.5 \pm 26.6$ \\
\hline Effect Size & $1.52(0.78-$ & & $1.10(0.40-$ & $1.61(086-$ & & $0.86(0.18-$ \\
GT:Control & $2.26)$ & & $1.81)$ & $2.36)$ & & $1.55)$ \\
\hline Effect Size & $1.37(0.65-$ & & $\begin{array}{c}1.05(0.35- \\
1.75)\end{array}$ & $\begin{array}{c}1.40(0.67- \\
2.12)\end{array}$ & & $0.97(0.28-$ \\
Sham:Control & $2.10)$ & & \multicolumn{5}{|c}{} \\
\hline
\end{tabular}

For ROM and PPT, separate repeated measures ANCOVAs, with the baseline score as the covariate, were used to assess differences among groups at immediate post and 24 hours post-intervention. For ipsilateral lateral flexion, there was no treatment main effect $(\mathrm{p}=0.126)$, however, GT showed increased ROM compared to the control ( $\mathrm{p}=0.043)$ with post-hoc testing. For contralateral lateral flexion, there was a treatment main effect $(\mathrm{p}=0.001)$, where GT and sham showed increased ROM compared to the control, $\mathrm{p} \leq 0.001$ and $\mathrm{p}=0.019$, respectively. There were no differences among groups for PPT $(\mathrm{p}=0.201)$ (Table 3). 
Table 3. ROM (cm) and PPT (kg) Scores

\begin{tabular}{|c|c|c|c|}
\hline Variable & GT & Sham & Control \\
\hline $\begin{array}{c}\text { Contralateral Lateral } \\
\text { Flexion Baseline }\end{array}$ & $9.90 \pm 2.30$ & $10.05 \pm 3.22$ & $9.71 \pm 2.44$ \\
\hline $\begin{array}{c}\text { Contralateral Lateral } \\
\text { Flexion Immediate Post }\end{array}$ & $8.34 \pm 2.21$ & $9.13 \pm 2.95$ & $9.62 \pm 1.96$ \\
\hline $\begin{array}{c}\text { Contralateral Lateral } \\
\text { Flexion Post 24 hours }\end{array}$ & $7.94 \pm 2.51$ & $8.66 \pm 2.88$ & $9.40 \pm 2.28$ \\
\hline $\begin{array}{c}\text { Ipsilateral Lateral } \\
\text { Flexion Baseline }\end{array}$ & $9.13 \pm 2.89$ & $9.69 \pm 2.98$ & $9.57 \pm 2.52$ \\
\hline $\begin{array}{c}\text { Ipsilateral Lateral } \\
\text { Flexion Immediate Post }\end{array}$ & $8.14 \pm 2.59$ & $9.16 \pm 2.73$ & $9.27 \pm 2.59$ \\
\hline $\begin{array}{c}\text { Ipsilateral Lateral } \\
\text { Flexion Post 24 hours }\end{array}$ & $8.13 \pm 2.28$ & $8.87 \pm 2.95$ & $9.17 \pm 2.41$ \\
\hline PPT Baseline & $8.23 \pm 2.85$ & $7.52 \pm 1.75$ & $7.95 \pm 2.53$ \\
\hline PPT Immediate Post & $8.25 \pm 2.91$ & $7.03 \pm 1.52$ & $7.48 \pm 2.52$ \\
\hline PPT Post 24 hours & $7.73 \pm 3.18$ & $6.52 \pm 1.12$ & $7.46 \pm 2.34$ \\
\hline
\end{tabular}




\section{CHAPTER V: DISCUSSION}

After completing a single treatment following the GT Protocol, the results of this study concluded GT instruments and an IASTM tool increased oxygenated hemoglobin, indicating increased blood flow immediately following treatment. There was an overall increase in ROM following GT for both contralateral and ipsilateral neck lateral flexion. Also, the IASTM sham intervention showed increases with contralateral neck lateral flexion. However, there were no differences in pain reduction measured by PPT across all participants. While the sham and GT increased blood flow to the treatment area, it is important to note the results in ROM had better outcomes from GT compared to a sham instrument. Although the results of this study did not show GT instruments as a superior treatment overall compared to an IASTM tool, the effects of both treatment tools provided benefits to those with NS-NP. In previous research, NS-NP patients presenting with trigger points in the upper trapezius muscle have been established as a result of a lack of blood flow to the muscle.5,6,8-12,14,20,31,35,255 Although research is limited on examining the direct effects of GT instrument on blood flow to the neck musculature, it has been proposed these instruments combined with specific strokes and standardized protocol, increases the rate and amount of blood flow to a treatment area more effectively than other IASTM tools.31 As shown by the results of this study, the use of an IASTM tool and GT instruments significantly increased the amount of blood flow perfusing the neck musculature, which may lead to the breakdown of trigger points. However, there is a need for further research to examine the effects on blood flow between different types of IASTM tools on the upper trapezius.

There is an immense amount of literature on the use of IASTM tools, including GT, that have proven to significantly decrease pain and improve ROM in numerous areas of the body.24,26-28,30,31,256 However, the literature presents pain in subjective and objective manners, 
including the use of a Visual Analog Scale (VAS) and PPT, respectively.24,28-31,172 Previous research on GT has shown significant decreases in VAS scores for patients suffering from low back pain, lateral ankle sprains, shoulder impingement, and cervical pain. 28,30,172 Lambert et al.172 describes a study that examined the effects of IASTM on cervical pain and showed a decrease in pain using the subjective measure of VAS. Current literature has also suggested different forms of IASTM, including GT, can significantly improve PPT in patients presenting with neck pain and trigger points in the upper trapezius.24,29,31,200 Miller et al.200 found significant increases in PPT values to objectively measure the sensitivity of upper trapezius trigger points with the application of GT. In this study, participants in the IASTM and GT group did not show a significant decrease in pain after a single treatment when compared to a control group.

However, all participants in this study went through the GT protocol and only received one, fiveminute IASTM treatment, which may have altered the results. A previous study by Gulick et al.24 found GT improved PPT on trigger points over a three-week period including six sessions. Also, PPT has been established as a valid and reliable measure of pain in trigger points $238-249$ but may not translate after a single treatment of IASTM application. Due to increased petechiae and tenderness over the treatment area, it is common for patients to experience increased pain following a single treatment 26,31,256 Therefore, a twenty-four hour post-intervention measure may not allow enough time for pain reduction to be identified. The results of this study showed an immediate increase in ipsilateral cervical lateral flexion ROM after GT and an increase in contralateral lateral flexion ROM after GT and sham instrument application. There is high level evidence that suggests there are significant improvements in ROM after using IASTM as a treatment insttrument.26-28,30,31 In this study, all participants followed the GT protocol regardless of group allocation, which included a lateral flexion stretch to the contralateral side of treatment. 
This confounding factor may have influenced the immediate increase in ipsilateral lateral flexion ROM as the upper trapezius causes ipsilateral lateral flexion.

\section{Limitations}

Limitations to this study include the assumption that participant neck pain was a result of trigger points, the variability of blood flow from person to person, and participant demographics. A threat to this study was the perception of participant neck pain being caused by the presence of trigger points in the upper trapezius. The participants in this study were included as a result of self-reported neck pain and the identification of a trigger point by a clinician. However, the clinician had no measurable means of assuring the trigger point(s) identified and treated were the root cause of each participants neck pain. Hemodynamics vary between each participant and it may have been more ideal to capture blood flow changes across the same participants in each group using a cross-over study design. As well, the participants in this study were mostly college-aged; therefore, the limited population causes the results to be difficult to generalize to other populations.

Future research should include an optimal population with more variety in age and employ a multi-faceted evaluation to grasp the nature of a participant's pain. As well, future studies should attempt a cross-over study design to better understand the hemodynamic effects caused by GT on the upper trapezius. Based on current literature, future research examining the effects of GT on blood flow should employ a longer treatment period instead of a single treatment session. After multiple treatment sessions, the relationship between GT and blood flow may be more visible and allow clinicians to gain a better understanding of this treatment technique. 


\section{Conclusion}

While the direct effects of GT on trigger points in the upper trapezius are still unknown, it is vital for future research to identify the role altered blood flow may play in pain and ROM in neck pain patients. Previous research has established IASTM and GT as treatment techniques for neck pain reduction.15,29,129-131 However, there is a need for future research to assess GT effects on blood flow, ROM, and pain overtime. The results in the present study found GT, another IASTM instrument, are viable instruments to increase blood flow and increase ROM for people with upper trapezius trigger points. Concurrently, stretching and exercise alone will not cause the same results in a twenty-four-hour period. In conclusion, this study found that after a single treatment, IASTM and the GT protocol have positive benefits on cervical ROM and blood flow to the upper trapezius in patients with neck pain. 


\section{WORKS CITED}

1. Bech KT, Larsen CM, Sjøgaard G, Holtermann A, Taylor JL, Søgaard K. Voluntary activation of the trapezius muscle in cases with neck/shoulder pain compared to healthy controls. J Electromyogr Kinesiol Off J Int Soc Electrophysiol Kinesiol. 2017;36:56-64. doi:10.1016/j.jelekin.2017.07.006

2. Kim E-K, Kim JS. Correlation between rounded shoulder posture, neck disability indices, and degree of forward head posture. J Phys Ther Sci. 2016;28(10):2929-2932. doi:10.1589/jpts.28.2929

3. Kwon JW, Son SM, Lee NK. Changes in upper-extremity muscle activities due to head position in subjects with a forward head posture and rounded shoulders. $J$ Phys Ther Sci. 2015;27(6):1739-1742. doi:10.1589/jpts.27.1739

4. Xie Y, Szeto GPY, Dai J, Madeleine P. A comparison of muscle activity in using touchscreen smartphone among young people with and without chronic neck-shoulder pain. Ergonomics. 2016;59(1):61-72. doi:10.1080/00140139.2015.1056237

5. Sadria G, Hosseini M, Rezasoltani A, Akbarzadeh Bagheban A, Davari A, Seifolahi A. A comparison of the effect of the active release and muscle energy techniques on the latent trigger points of the upper trapezius. J Bodyw Mov Ther. 2017;21(4):920-925. doi:10.1016/j.jbmt.2016.10.005

6. Nicoletti C, Spengler CM, Läubli T. Physical workload, trapezius muscle activity, and neck pain in nurses' night and day shifts: a physiological evaluation. Appl Ergon. 2014;45(3):741-746. doi:10.1016/j.apergo.2013.09.016

7. Thigpen CA, Padua DA, Michener LA, et al. Head and shoulder posture affect scapular mechanics and muscle activity in overhead tasks. J Electromyogr Kinesiol Off J Int Soc Electrophysiol Kinesiol. 2010;20(4):701-709. doi:10.1016/j.jelekin.2009.12.003

8. Clark BC, Thomas JS, Walkowski SA, Howell JN. The biology of manual therapies. J Am Osteopath Assoc. 2012;112(9):617-629.

9. Muñoz-Muñoz S, Muñoz-García MT, Alburquerque-Sendín F, Arroyo-Morales M, Fernández-de-las-Peñas C. Myofascial trigger points, pain, disability, and sleep quality in individuals with mechanical neck pain. J Manipulative Physiol Ther. 2012;35(8):608-613. doi:10.1016/j.jmpt.2012.09.003

10. Fernández-de-las-Peñas C, Alonso-Blanco C, Miangolarra JC. Myofascial trigger points in subjects presenting with mechanical neck pain: a blinded, controlled study. Man Ther. 2007;12(1):29-33. doi:10.1016/j.math.2006.02.002

11. Yap E-C. Myofascial pain--an overview. Ann Acad Med Singapore. 2007;36(1):43-48. 
12. Rickards LD. The Effectiveness of Non-Invasive Treatments for Active Myofascial Trigger Point Pain: A Systematic Review of the Literature. Centre for Reviews and Dissemination (UK); 2006. https://www.ncbi.nlm.nih.gov/books/NBK72610/. Accessed May 14, 2019.

13. Nagrale AV, Glynn P, Joshi A, Ramteke G. The efficacy of an integrated neuromuscular inhibition technique on upper trapezius trigger points in subjects with non-specific neck pain: a randomized controlled trial. J Man Manip Ther. 2010;18(1):37-43. doi: $10.1179 / 106698110 X 12595770849605$

14. Simons DG. Travell \& Simons' Myofascial Pain and Dysfunction: The Trigger Point Manual /. 2nd ed. Baltimore: Williams \& Wilkins,; 1999.

15. Binder A. The diagnosis and treatment of nonspecific neck pain and whiplash. Eur Medicophysica. 2007;43(1):79-89.

16. Binder AI. Neck pain. BMJ Clin Evid. 2008;2008.

17. Calamita SAP, Biasotto-Gonzalez DA, De Melo NC, et al. Immediate Effect of Acupuncture on Electromyographic Activity of the Upper Trapezius Muscle and Pain in Patients With Nonspecific Neck Pain: A Randomized, Single-Blinded, Sham-Controlled, Crossover Study. J Manipulative Physiol Ther. 2018;41(3):208-217. doi:10.1016/j.jmpt.2017.09.006

18. Fejer R, Kyvik KO, Hartvigsen J. The prevalence of neck pain in the world population: a systematic critical review of the literature. Eur Spine J Off Publ Eur Spine Soc Eur Spinal Deform Soc Eur Sect Cerv Spine Res Soc. 2006;15(6):834-848. doi:10.1007/s00586-0040864-4

19. Murray CJL, Atkinson C, Bhalla K, et al. The state of US health, 1990-2010: burden of diseases, injuries, and risk factors. JAMA. 2013;310(6):591-608. doi:10.1001/jama.2013.13805

20. Cohen SP, Hooten WM. Advances in the diagnosis and management of neck pain. $B M J$. 2017;358:j3221. doi:10.1136/bmj.j3221

21. Côté P, van der Velde G, Cassidy JD, et al. The burden and determinants of neck pain in workers: results of the Bone and Joint Decade 2000-2010 Task Force on Neck Pain and Its Associated Disorders. Spine. 2008;33(4 Suppl):S60-74. doi:10.1097/BRS.0b013e3181643ee4

22. Chiarotto A, Clijsen R, Fernandez-de-Las-Penas C, Barbero M. Prevalence of Myofascial Trigger Points in Spinal Disorders: A Systematic Review and Meta-Analysis. Arch Phys Med Rehabil. 2016;97(2):316-337. doi:10.1016/j.apmr.2015.09.021

23. Ganesh GS, Singh H, Mushtaq S, Mohanty P, Pattnaik M. Effect of cervical mobilization and ischemic compression therapy on contralateral cervical side flexion and pressure pain threshold in latent upper trapezius trigger points. J Bodyw Mov Ther. 2016;20(3):477-483. doi:10.1016/j.jbmt.2015.11.010 
24. Gulick DT. Influence of instrument assisted soft tissue treatment techniques on myofascial trigger points. J Bodyw Mov Ther. 2014;18(4):602-607. doi:10.1016/j.jbmt.2014.02.004

25. Howitt S, Wong J, Zabukovec S. The conservative treatment of Trigger thumb using Graston Techniques and Active Release Techniques. J Can Chiropr Assoc. 2006;50(4):249-254.

26. Cheatham SW, Lee M, Cain M, Baker R. The efficacy of instrument assisted soft tissue mobilization: a systematic review. J Can Chiropr Assoc. 2016;60(3):200-211.

27. Kim J, Sung DJ, Lee J. Therapeutic effectiveness of instrument-assisted soft tissue mobilization for soft tissue injury: mechanisms and practical application. $J$ Exerc Rehabil. 2017;13(1):12-22. doi:10.12965/jer.1732824.412

28. Lee J-H, Lee D-K, Oh J-S. The effect of Graston technique on the pain and range of motion in patients with chronic low back pain. J Phys Ther Sci. 2016;28(6):1852-1855. doi:10.1589/jpts.28.1852

29. Gulick DT. Instrument-assisted soft tissue mobilization increases myofascial trigger point pain threshold. J Bodyw Mov Ther. 2018;22(2):341-345. doi:10.1016/j.jbmt.2017.10.012

30. Moon JH, Jung J-H, Won YS, Cho H-Y. Immediate effects of Graston Technique on hamstring muscle extensibility and pain intensity in patients with nonspecific low back pain. J Phys Ther Sci. 2017;29(2):224-227. doi:10.1589/jpts.29.224

31. M Carey-Loghmani, Schrader J, Hammer W. Graston Technique, LLC Therapy M1 Instruction Manual.

32. Wilke J, Schleip R, Yucesoy CA, Banzer W. Not merely a protective packing organ? A review of fascia and its force transmission capacity. J Appl Physiol Bethesda Md 1985. 2018;124(1):234-244. doi:10.1152/japplphysiol.00565.2017

33. Norton-Old KJ, Schache AG, Barker PJ, Clark RA, Harrison SM, Briggs CA. Anatomical and mechanical relationship between the proximal attachment of adductor longus and the distal rectus sheath. Clin Anat N Y N. 2013;26(4):522-530. doi:10.1002/ca.22116

34. Crothers A, Walker B, French SD. Spinal manipulative therapy versus Graston Technique in the treatment of non-specific thoracic spine pain: design of a randomised controlled trial. Chiropr Osteopat. 2008;16:12. doi:10.1186/1746-1340-16-12

35. Mense S. Muscle Pain : Understanding Its Nature, Diagnosis, and Treatment/. Philadelphia : Lippincott Williams \& Wilkins,; c2001.

36. Joodaki H, Panzer MB. Skin mechanical properties and modeling: A review. Proc Inst Mech Eng [H]. 2018;232(4):323-343. doi:10.1177/0954411918759801

37. Burns T, Breathnach S, Cox N, Griffiths C. Rook's Textbook of Dermatology. John Wiley \& Sons; 2013. 
38. Hussain SH, Limthongkul B, Humphreys TR. The biomechanical properties of the skin. Dermatol Surg Off Publ Am Soc Dermatol Surg Al. 2013;39(2):193-203. doi:10.1111/dsu.12095

39. Marieb EN, Hoehn K. Human Anatomy \& Physiology. Pearson; 2016.

40. Hendriks F. Mechanical Behaviour of Human Skin in Vivo. In: ; 2001.

41. Goldsmith LA. Biochemistry and Physiology of the Skin. Oxford University Press; 1983.

42. Laurent A, Mistretta F, Bottigioli D, et al. Echographic measurement of skin thickness in adults by high frequency ultrasound to assess the appropriate microneedle length for intradermal delivery of vaccines. Vaccine. 2007;25(34):6423-6430. doi:10.1016/j.vaccine.2007.05.046

43. Goldsmith LA. Physiology, Biochemistry, and Molecular Biology of the Skin. 2nd ed. New York : Oxford University Press; 1991. https://trove.nla.gov.au/version/6969658. Accessed June 19, 2019.

44. Uitto J. Biochemistry of the elastic fibers in normal connective tissues and its alterations in diseases. J Invest Dermatol. 1979;72(1):1-10.

45. Ebling F, Eady R, Leigh I. Anatomy and Organization of Human Skin. London: Blackwell: Textbook of dermatology; 1992.

46. Oxlund H, Manschot J, Viidik A. The role of elastin in the mechanical properties of skin. $J$ Biomech. 1988;21(3):213-218.

47. Wilkes GL, Brown IA, Wildnauer RH. The biomechanical properties of skin. CRC Crit Rev Bioeng. 1973;1(4):453-495.

48. Katz SI, Gilchrest BA, Paller A, Wolff K, Leffell DJ. Fitzpatrick's Dermatology in General Medicine, Eighth Edition, 2 Volume Set. McGraw Hill Professional; 2012.

49. Larrabee W, Bloom D. Biomechanics of Skin Flaps. 2nd ed. Philadelphia. Elsevir: Baker S. editor; 2007. https://clinicalgate.com/biomechanics-of-skin-flaps/. Accessed June 20, 2019.

50. Wilhelmi BJ, Blackwell SJ, Mancoll JS, Phillips LG. Creep vs. stretch: a review of the viscoelastic properties of skin. Ann Plast Surg. 1998;41(2):215-219.

51. Dictionary AH. The American Heritage Medical Dictionary. Houghton Mifflin Company; 2007.

52. Stecco C, Macchi V, Porzionato A, Duparc F, De Caro R. The fascia: the forgotten structure. Ital J Anat Embryol Arch Ital Anat Ed Embriologia. 2011;116(3):127-138. 
53. Wilke J, Krause F, Vogt L, Banzer W. What Is Evidence-Based About Myofascial Chains: A Systematic Review. Arch Phys Med Rehabil. 2016;97(3):454-461.

doi:10.1016/j.apmr.2015.07.023

54. Myers TW. Anatomy Trains: Myofascial Meridians for Manual and Movement Therapists. 3rd ed. Elsevier Health Sciences; 2009.

55. Langevin HM. Connective tissue: a body-wide signaling network? Med Hypotheses. 2006;66(6):1074-1077. doi:10.1016/j.mehy.2005.12.032

56. Langevin HM, Bouffard NA, Badger GJ, Churchill DL, Howe AK. Subcutaneous tissue fibroblast cytoskeletal remodeling induced by acupuncture: evidence for a mechanotransduction-based mechanism. J Cell Physiol. 2006;207(3):767-774. doi:10.1002/jcp.20623

57. Lindsay M, Robertson C. Fascia: Clinical Applications for Health and Human Performance. Delmar; 2008.

58. Kassolik K, Jaskólska A, Kisiel-Sajewicz K, Marusiak J, Kawczyński A, Jaskólski A. Tensegrity principle in massage demonstrated by electro- and mechanomyography. $J$ Bodyw Mov Ther. 2009;13(2):164-170. doi:10.1016/j.jbmt.2007.11.002

59. Stecco C, Porzionato A, Lancerotto L, et al. Histological study of the deep fasciae of the limbs. J Bodyw Mov Ther. 2008;12(3):225-230. doi:10.1016/j.jbmt.2008.04.041

60. Stecco A, Macchi V, Masiero S, et al. Pectoral and femoral fasciae: common aspects and regional specializations. Surg Radiol Anat SRA. 2009;31(1):35-42. doi:10.1007/s00276008-0395-5

61. Abu-Hijleh MF, Roshier AL, Al-Shboul Q, Dharap AS, Harris PF. The membranous layer of superficial fascia: evidence for its widespread distribution in the body. Surg Radiol Anat SRA. 2006;28(6):606-619. doi:10.1007/s00276-006-0142-8

62. Stecco C. Functional Atlas of the Human Fascial System E-Book. Elsevier Health Sciences; 2014.

63. Hammer W. EFFECTS OF GRASTON TECHNIQUE® ON THE FASCIAL SYSTEM. 2014:4.

64. Stecco C, Stern R, Porzionato A, et al. Hyaluronan within fascia in the etiology of myofascial pain. Surg Radiol Anat SRA. 2011;33(10):891-896. doi:10.1007/s00276-0110876-9

65. Gerlach UJ, Lierse W. Functional construction of the superficial and deep fascia system of the lower limb in man. Acta Anat (Basel). 1990;139(1):11-25.

66. Young B, Lowe JS, Stevens A, Heath JW, Deakin PJ. Wheater's Functional Histology. Elsevier Health Sciences; 2006. 
67. Huijing PA. Epimuscular myofascial force transmission: a historical review and implications for new research. International Society of Biomechanics Muybridge Award Lecture, Taipei, 2007. J Biomech. 2009;42(1):9-21. doi:10.1016/j.jbiomech.2008.09.027

68. Yucesoy CA. Epimuscular myofascial force transmission implies novel principles for muscular mechanics. Exerc Sport Sci Rev. 2010;38(3):128-134. doi:10.1097/JES.0b013e3181e372ef

69. Bhattacharya V, Barooah PS, Nag TC, Chaudhuri GR, Bhattacharya S. Detail microscopic analysis of deep fascia of lower limb and its surgical implication. Indian J Plast Surg Off Publ Assoc Plast Surg India. 2010;43(2):135-140. doi:10.4103/0970-0358.73424

70. Stecco L, Stecco C. Fascial Manipulation: Practical Part. Piccin; 2009.

71. Stecco C, Corradin M, Macchi V, et al. Plantar fascia anatomy and its relationship with Achilles tendon and paratenon. J Anat. 2013;223(6):665-676. doi:10.1111/joa.12111

72. Stecco C, Gagey O, Belloni A, et al. Anatomy of the deep fascia of the upper limb. Second part: study of innervation. Morphol Bull Assoc Anat. 2007;91(292):38-43. doi:10.1016/j.morpho.2007.05.002

73. Tesarz J, Hoheisel U, Wiedenhöfer B, Mense S. Sensory innervation of the thoracolumbar fascia in rats and humans. Neuroscience. 2011;194:302-308. doi:10.1016/j.neuroscience.2011.07.066

74. Yahia L, Rhalmi S, Newman N, Isler M. Sensory innervation of human thoracolumbar fascia. An immunohistochemical study. Acta Orthop Scand. 1992;63(2):195-197.

75. Wilke J, Schleip R, Klingler W, Stecco C. The Lumbodorsal Fascia as a Potential Source of Low Back Pain: A Narrative Review. BioMed Res Int. 2017;2017:5349620. doi: $10.1155 / 2017 / 5349620$

76. Caggiati A. Fascial relations and structure of the tributaries of the saphenous veins. Surg Radiol Anat SRA. 2000;22(3-4):191-196.

77. Huijing PA, Baan GC, Rebel GT. Non-myotendinous force transmission in rat extensor digitorum longus muscle. J Exp Biol. 1998;201(Pt 5):683-691.

78. Huijing P. Muscular force transmission: a unified, dual or multiple system? A review and some explorative experimental results. Arch Physiol Biochem. 1999;107(4):292-311. doi:10.1076/13813455199908107041QFT292

79. Huijing PA, Baan GC. Myofascial force transmission causes interaction between adjacent muscles and connective tissue: effects of blunt dissection and compartmental fasciotomy on length force characteristics of rat extensor digitorum longus muscle. Arch Physiol Biochem. 2001;109(2):97-109. doi:10.1076/apab.109.2.97.4269 
80. Huijing PA, Baan GC. Extramuscular myofascial force transmission within the rat anterior tibial compartment: proximo-distal differences in muscle force. Acta Physiol Scand. 2001;173(3):297-311. doi:10.1046/j.1365-201X.2001.00911.x

81. Yucesoy CA, Maas H, Koopman BHFJM, Grootenboer HJ, Huijing PA. Mechanisms causing effects of muscle position on proximo-distal muscle force differences in extramuscular myofascial force transmission. Med Eng Phys. 2006;28(3):214-226. doi:10.1016/j.medengphy.2005.06.004

82. Vleeming A, Pool-Goudzwaard AL, Hammudoghlu D, Stoeckart R, Snijders CJ, Mens JM. The function of the long dorsal sacroiliac ligament: its implication for understanding low back pain. Spine. 1996;21(5):556-562.

83. Vleeming A, Pool-Goudzwaard AL, Stoeckart R, van Wingerden JP, Snijders CJ. The posterior layer of the thoracolumbar fascia. Its function in load transfer from spine to legs. Spine. 1995;20(7):753-758.

84. Jones FW. Structure and Function as Seen in the Foot. Baillière, Tindall and Cox; 1944.

85. Benjamin M. The fascia of the limbs and back--a review. J Anat. 2009;214(1):1-18. doi:10.1111/j.1469-7580.2008.01011.x

86. Stecco L. Fascial Manipulation for Muscuskeletal Pain. Piccin Nuova Libraria S.p.A.; 2004.

87. Schleip R, Duerselen L, Vleeming A, et al. Strain hardening of fascia: static stretching of dense fibrous connective tissues can induce a temporary stiffness increase accompanied by enhanced matrix hydration. J Bodyw Mov Ther. 2012;16(1):94-100. doi:10.1016/j.jbmt.2011.09.003

88. Yahia LH, Pigeon P, DesRosiers EA. Viscoelastic properties of the human lumbodorsal fascia. J Biomed Eng. 1993;15(5):425-429.

89. Chimich D, Shrive N, Frank C, Marchuk L, Bray R. Water content alters viscoelastic behaviour of the normal adolescent rabbit medial collateral ligament. J Biomech. 1992;25(8):831-837.

90. Haut TL, Haut RC. The state of tissue hydration determines the strain-rate-sensitive stiffness of human patellar tendon. J Biomech. 1997;30(1):79-81.

91. Thornton GM, Shrive NG, Frank CB. Altering ligament water content affects ligament prestress and creep behaviour. J Orthop Res Off Publ Orthop Res Soc. 2001;19(5):845-851. doi:10.1016/S0736-0266(01)00005-5

92. Barker PJ, Briggs CA, Bogeski G. Tensile transmission across the lumbar fasciae in unembalmed cadavers: effects of tension to various muscular attachments. Spine. 2004;29(2):129-138. doi:10.1097/01.BRS.0000107005.62513.32 
93. Benjamin M, Kaiser E, Milz S. Structure-function relationships in tendons: a review. J Anat. 2008;212(3):211-228. doi:10.1111/j.1469-7580.2008.00864.x

94. Maas H, Sandercock TG. Force transmission between synergistic skeletal muscles through connective tissue linkages. J Biomed Biotechnol. 2010;2010:575672. doi: $10.1155 / 2010 / 575672$

95. Purslow PP. Muscle fascia and force transmission. J Bodyw Mov Ther. 2010;14(4):411-417. doi:10.1016/j.jbmt.2010.01.005

96. Huijing PA, Maas H, Baan GC. Compartmental fasciotomy and isolating a muscle from neighboring muscles interfere with myofascial force transmission within the rat anterior crural compartment. J Morphol. 2003;256(3):306-321. doi:10.1002/jmor.10097

97. Ghaderi F, Jafarabadi MA, Javanshir K. The clinical and EMG assessment of the effects of stabilization exercise on nonspecific chronic neck pain: A randomized controlled trial. $J$ Back Musculoskelet Rehabil. 2017;30(2):211-219. doi:10.3233/BMR-160735

98. Biel A. Trail Guide to the Body 5e: A Hands-On Guide to Locating Muscles, Bones and More. Books of Discovery; 2014.

99. Bland JH, Boushey DR. Anatomy and physiology of the cervical spine. Semin Arthritis Rheum. 1990;20(1):1-20.

100. Aker PD, Gross AR, Goldsmith CH, Peloso P. Conservative management of mechanical neck pain: systematic overview and meta-analysis. BMJ. 1996;313(7068):1291-1296.

101. Côté P, Cassidy JD, Carroll L. The Saskatchewan Health and Back Pain Survey. The prevalence of neck pain and related disability in Saskatchewan adults. Spine. 1998;23(15):1689-1698.

102. Mäkelä M, Heliövaara M, Sievers K, Impivaara O, Knekt P, Aromaa A. Prevalence, determinants, and consequences of chronic neck pain in Finland. Am J Epidemiol. 1991;134(11):1356-1367. doi:10.1093/oxfordjournals.aje.a116038

103. Ariëns GAM, Bongers PM, Hoogendoorn WE, van der Wal G, van Mechelen W. High physical and psychosocial load at work and sickness absence due to neck pain. Scand J Work Environ Health. 2002;28(4):222-231.

104. Côté P, Cassidy JD, Carroll LJ, Kristman V. The annual incidence and course of neck pain in the general population: a population-based cohort study. Pain. 2004;112(3):267-273. doi:10.1016/j.pain.2004.09.004

105. Green BN. A literature review of neck pain associated with computer use: public health implications. J Can Chiropr Assoc. 2008;52(3):161-167. 
106. Griffiths C, Dziedzic K, Waterfield J, Sim J. Effectiveness of specific neck stabilization exercises or a general neck exercise program for chronic neck disorders: a randomized controlled trial. J Rheumatol. 2009;36(2):390-397. doi:10.3899/jrheum.080376

107. Spitzer WO, Skovron ML, Salmi LR, et al. Scientific monograph of the Quebec Task Force on Whiplash-Associated Disorders: redefining "whiplash" and its management. Spine. 1995;20(8 Suppl):1S-73S.

108. Borghouts JA, Koes BW, Vondeling H, Bouter LM. Cost-of-illness of neck pain in The Netherlands in 1996. Pain. 1999;80(3):629-636.

109. Hagberg M, Wegman DH. Prevalence rates and odds ratios of shoulder-neck diseases in different occupational groups. Br J Ind Med. 1987;44(9):602-610. doi:10.1136/oem.44.9.602

110. Croft PR, Lewis M, Papageorgiou AC, et al. Risk factors for neck pain: a longitudinal study in the general population. Pain. 2001;93(3):317-325.

111. Nilsen TIL, Holtermann A, Mork PJ. Physical exercise, body mass index, and risk of chronic pain in the low back and neck/shoulders: longitudinal data from the NordTrondelag Health Study. Am J Epidemiol. 2011;174(3):267-273. doi:10.1093/aje/kwr087

112. Kääriä S, Laaksonen M, Rahkonen O, Lahelma E, Leino-Arjas P. Risk factors of chronic neck pain: a prospective study among middle-aged employees. Eur J Pain Lond Engl. 2012;16(6):911-920. doi:10.1002/j.1532-2149.2011.00065.x

113. Linton SJ. A review of psychological risk factors in back and neck pain. Spine. 2000;25(9):1148-1156.

114. Kristjansson E, Jónsson H. Is the sagittal configuration of the cervical spine changed in women with chronic whiplash syndrome? A comparative computer-assisted radiographic assessment. J Manipulative Physiol Ther. 2002;25(9):550-555. doi: $10.1067 / \mathrm{mmt} .2002 .128371$

115. Kristjansson E, Leivseth G, Brinckmann P, Frobin W. Increased sagittal plane segmental motion in the lower cervical spine in women with chronic whiplash-associated disorders, grades I-II: a case-control study using a new measurement protocol. Spine. 2003;28(19):2215-2221. doi:10.1097/01.BRS.0000089525.59684.49

116. Silverman JL, Rodriquez AA, Agre JC. Quantitative cervical flexor strength in healthy subjects and in subjects with mechanical neck pain. Arch Phys Med Rehabil. 1991;72(9):679-681.

117. Hides JA, Richardson CA, Jull GA. Multifidus muscle recovery is not automatic after resolution of acute, first-episode low back pain. Spine. 1996;21(23):2763-2769.

118. Panjabi MM. The stabilizing system of the spine. Part II. Neutral zone and instability hypothesis. J Spinal Disord. 1992;5(4):390-396; discussion 397. 
119. Falla D. Unravelling the complexity of muscle impairment in chronic neck pain. Man Ther. 2004;9(3):125-133. doi:10.1016/j.math.2004.05.003

120. Audette JF, Wang F, Smith H. Bilateral activation of motor unit potentials with unilateral needle stimulation of active myofascial trigger points. Am J Phys Med Rehabil. 2004;83(5):368-374, quiz 375-377, 389.

121. Wytrazek M, Huber J, Lisinski P. Changes in muscle activity determine progression of clinical symptoms in patients with chronic spine-related muscle pain. A complex clinical and neurophysiological approach. Funct Neurol. 2011;26(3):141-149.

122. Scott NA, Guo B, Barton PM, Gerwin RD. Trigger point injections for chronic nonmalignant musculoskeletal pain: a systematic review. Pain Med Malden Mass. 2009;10(1):54-69. doi:10.1111/j.1526-4637.2008.00526.x

123. Kuan T-S. Current studies on myofascial pain syndrome. Curr Pain Headache Rep. 2009;13(5):365-369.

124. Wegner S, Jull G, O’Leary S, Johnston V. The effect of a scapular postural correction strategy on trapezius activity in patients with neck pain. Man Ther. 2010;15(6):562-566. doi:10.1016/j.math.2010.06.006

125. Miller J, Gross A, D’Sylva J, et al. Manual therapy and exercise for neck pain: A systematic review. Man Ther. June 2010. doi:10.1016/j.math.2010.02.007

126. Pangarkar S, Lee PC. Conservative treatment for neck pain: medications, physical therapy, and exercise. Phys Med Rehabil Clin N Am. 2011;22(3):503-520, ix. doi:10.1016/j.pmr.2011.04.001

127. Ylinen J, Takala E-P, Nykänen M, et al. Active neck muscle training in the treatment of chronic neck pain in women: a randomized controlled trial. JAMA. 2003;289(19):25092516. doi:10.1001/jama.289.19.2509

128. Waling K, Sundelin G, Ahlgren C, Järvholm B. Perceived pain before and after three exercise programs--a controlled clinical trial of women with work-related trapezius myalgia. Pain. 2000;85(1-2):201-207.

129. Jordan A, Bendix T, Nielsen H, Hansen FR, Høst D, Winkel A. Intensive training, physiotherapy, or manipulation for patients with chronic neck pain. A prospective, singleblinded, randomized clinical trial. Spine. 1998;23(3):311-318; discussion 319.

130. Koes BW, Bouter LM, van Mameren H, et al. Randomised clinical trial of manipulative therapy and physiotherapy for persistent back and neck complaints: results of one year follow up. BMJ. 1992;304(6827):601-605. doi:10.1136/bmj.304.6827.601

131. Hoving JL, Koes BW, de Vet HCW, et al. Manual therapy, physical therapy, or continued care by a general practitioner for patients with neck pain. A randomized, controlled trial. Ann Intern Med. 2002;136(10):713-722. doi:10.7326/0003-4819-136-10-200205210-00006 
132. Bronfort G, Evans R, Nelson B, Aker PD, Goldsmith CH, Vernon H. A randomized clinical trial of exercise and spinal manipulation for patients with chronic neck pain. Spine. 2001;26(7):788-797; discussion 798-799.

133. Evans R, Bronfort G, Nelson B, Goldsmith CH. Two-year follow-up of a randomized clinical trial of spinal manipulation and two types of exercise for patients with chronic neck pain. Spine. 2002;27(21):2383-2389. doi:10.1097/01.BRS.0000030192.39326.FF

134. Segura-Ortí E, Prades-Vergara S, Manzaneda-Piña L, Valero-Martínez R, Polo-Traverso JA. Trigger point dry needling versus strain-counterstrain technique for upper trapezius myofascial trigger points: a randomised controlled trial. Acupunct Med J Br Med Acupunct Soc. 2016;34(3):171-177. doi:10.1136/acupmed-2015-010868

135. Cagnie B, Castelein B, Pollie F, Steelant L, Verhoeyen H, Cools A. Evidence for the Use of Ischemic Compression and Dry Needling in the Management of Trigger Points of the Upper Trapezius in Patients with Neck Pain: A Systematic Review. Am J Phys Med Rehabil. 2015;94(7):573-583. doi:10.1097/PHM.0000000000000266

136. Hanney WJ, Puentedura EJ, Kolber MJ, Liu X, Pabian PS, Cheatham SW. The immediate effects of manual stretching and cervicothoracic junction manipulation on cervical range of motion and upper trapezius pressure pain thresholds. J Back Musculoskelet Rehabil. 2017;30(5):1005-1013. doi:10.3233/BMR-169573

137. Mohamadi M, Piroozi S, Rashidi I, Hosseinifard S. Friction massage versus kinesiotaping for short-term management of latent trigger points in the upper trapezius: a randomized controlled trial. Chiropr Man Ther. 2017;25:25. doi:10.1186/s12998-017-0156-9

138. Abbaszadeh-Amirdehi M, Ansari NN, Naghdi S, Olyaei G, Nourbakhsh MR. Therapeutic effects of dry needling in patients with upper trapezius myofascial trigger points. Acupunct Med J Br Med Acupunct Soc. 2017;35(2):85-92. doi:10.1136/acupmed-2016-011082

139. Vernon HT, Humphreys BK, Hagino CA. A systematic review of conservative treatments for acute neck pain not due to whiplash. J Manipulative Physiol Ther. 2005;28(6):443-448. doi:10.1016/j.jmpt.2005.06.011

140. Canadian Chiropractic Association, Canadian Federation of Chiropractic Regulatory Boards, Clinical Practice Guidelines Development Initiative, et al. Chiropractic clinical practice guideline: evidence-based treatment of adult neck pain not due to whiplash. $J$ Can Chiropr Assoc. 2005;49(3):158-209.

141. Hurwitz EL, Aker PD, Adams AH, Meeker WC, Shekelle PG. Manipulation and mobilization of the cervical spine. A systematic review of the literature. Spine. 1996;21(15):1746-1759; discussion 1759-1760.

142. Gross AR, Hoving JL, Haines TA, et al. Manipulation and mobilisation for mechanical neck disorders. Cochrane Database Syst Rev. 2004;(1):CD004249. doi:10.1002/14651858.CD004249.pub2 
143. Bronfort G, Haas M, Evans RL, Bouter LM. Efficacy of spinal manipulation and mobilization for low back pain and neck pain: a systematic review and best evidence synthesis. Spine J Off J North Am Spine Soc. 2004;4(3):335-356.

doi:10.1016/j.spinee.2003.06.002

144. Kay TM, Gross A, Goldsmith C, et al. Exercises for mechanical neck disorders. Cochrane Database Syst Rev. 2005;(3):CD004250. doi:10.1002/14651858.CD004250.pub3

145. Waling K, Järvholm B, Sundelin G. Effects of training on female trapezius Myalgia: An intervention study with a 3-year follow-up period. Spine. 2002;27(8):789-796.

146. Revel M, Minguet M, Gregoy P, Vaillant J, Manuel JL. Changes in cervicocephalic kinesthesia after a proprioceptive rehabilitation program in patients with neck pain: a randomized controlled study. Arch Phys Med Rehabil. 1994;75(8):895-899.

147. Yuan Q, Guo T, Liu L, Sun F, Zhang Y. Traditional Chinese medicine for neck pain and low back pain: a systematic review and meta-analysis. PloS One. 2015;10(2):e0117146. doi:10.1371/journal.pone.0117146

148. Harris PE, Cooper KL, Relton C, Thomas KJ. Prevalence of complementary and alternative medicine (CAM) use by the general population: a systematic review and update. Int J Clin Pract. 2012;66(10):924-939. doi:10.1111/j.1742-1241.2012.02945.x

149. Cooper KL, Harris PE, Relton C, Thomas KJ. Prevalence of visits to five types of complementary and alternative medicine practitioners by the general population: a systematic review. Complement Ther Clin Pract. 2013;19(4):214-220. doi:10.1016/j.ctcp.2013.06.006

150. Hsieh L-F, Hong C-Z, Chern S-H, Chen C-C. Efficacy and side effects of diclofenac patch in treatment of patients with myofascial pain syndrome of the upper trapezius. J Pain Symptom Manage. 2010;39(1):116-125. doi:10.1016/j.jpainsymman.2009.05.016

151. Predel H-G, Giannetti B, Pabst H, Schaefer A, Hug AM, Burnett I. Efficacy and safety of diclofenac diethylamine $1.16 \%$ gel in acute neck pain: a randomized, double-blind, placebo-controlled study. BMC Musculoskelet Disord. 2013;14:250. doi:10.1186/14712474-14-250

152. Haroutiunian S, Drennan DA, Lipman AG. Topical NSAID therapy for musculoskeletal pain. Pain Med Malden Mass. 2010;11(4):535-549. doi:10.1111/j.1526-4637.2010.00809.x

153. Kivlan BR, Carcia CR, Clemente FR, Phelps AL, Martin RL. The effect of Astym ${ }^{\circledR}$ Therapy on muscle strength: a blinded, randomized, clinically controlled trial. BMC Musculoskelet Disord. 2015;16:325. doi:10.1186/s12891-015-0778-9

154. Sevier TL. Traditional physical therapy vs Graston technique augmented soft tissue mobilization in treatment of lateral epicondylitis. JASCM. 1995;27(5):1-5. 
155. Markovic G. Acute effects of instrument assisted soft tissue mobilization vs. foam rolling on knee and hip range of motion in soccer players. J Bodyw Mov Ther. 2015;19(4):690-696. doi:10.1016/j.jbmt.2015.04.010

156. Hammer WI. The effect of mechanical load on degenerated soft tissue. J Bodyw Mov Ther. 2008;12(3):246-256. doi:10.1016/j.jbmt.2008.03.007

157. Nielsen A, Knoblauch NTM, Dobos GJ, Michalsen A, Kaptchuk TJ. The effect of Gua Sha treatment on the microcirculation of surface tissue: a pilot study in healthy subjects. Explore N Y N. 2007;3(5):456-466. doi:10.1016/j.explore.2007.06.001

158. Gehlsen GM, Ganion LR, Helfst R. Fibroblast responses to variation in soft tissue mobilization pressure. Med Sci Sports Exerc. 1999;31(4):531-535.

159. Melham TJ, Sevier TL, Malnofski MJ, Wilson JK, Helfst RH. Chronic ankle pain and fibrosis successfully treated with a new noninvasive augmented soft tissue mobilization technique (ASTM): a case report. Med Sci Sports Exerc. 1998;30(6):801-804.

160. Black DW. Treatment of knee arthrofibrosis and quadriceps insufficiency after patellar tendon repair: a case report including use of the graston technique. Int J Ther Massage Bodyw. 2010;3(2):14-21.

161. Chiu J-Y, Gau M-L, Kuo S-Y, Chang Y-H, Kuo S-C, Tu H-C. Effects of Gua-Sha therapy on breast engorgement: a randomized controlled trial. J Nurs Res JNR. 2010;18(1):1-10. doi:10.1097/JNR.0b013e3181ce4f8e

162. Howitt S, Jung S, Hammonds N. Conservative treatment of a tibialis posterior strain in a novice triathlete: a case report. J Can Chiropr Assoc. 2009;53(1):23-31.

163. Strunk RG, Pfefer MT, Dube D. Multimodal Chiropractic Care of Pain and Disability for a Patient Diagnosed With Benign Joint Hypermobility Syndrome: A Case Report. J Chiropr Med. 2014;13(1):35-42. doi:10.1016/j.jcm.2014.01.009

164. Davidson CJ, Ganion LR, Gehlsen GM, Verhoestra B, Roepke JE, Sevier TL. Rat tendon morphologic and functional changes resulting from soft tissue mobilization. Med Sci Sports Exerc. 1997;29(3):313-319.

165. Sevier TL, Stegink-Jansen CW. Astym treatment vs. eccentric exercise for lateral elbow tendinopathy: a randomized controlled clinical trial. PeerJ. 2015;3:e967. doi:10.7717/peerj.967

166. Park J, Oh E, Lee H, Kim Y, Shin Y. A case report on a patient of Achilles tendinitis treated with Gyeon-mak chuna, Korean medicine and Grasaton Technique. J Korean Acad Rehabil Med. 2015;25:103-110.

167. Papa JA. Conservative management of De Quervain's stenosing tenosynovitis: a case report. J Can Chiropr Assoc. 2012;56(2):112-120. 
168. McConnell J, Cruser S, Warden S, Bayliss A. Instrument-assisted soft tissue mobilization alters material and mechanical properties in Achilles tendinopathy. J Orthop Sports Phys Ther. 2016;46:114.

169. Bayliss A, Crandall T, Farmer D, Warden S. Instrument-assisted soft tissue mobilization alters material and mechanical properties in healthy, shortened Achilles tendons. J Orthop Sports Phys Ther. 2015;45:24.

170. Leahy M. Improved treatments for carpal tunnel \& related syndromes. Chiropr Sports Med. 1995;9(1):6-9.

171. Loghmani M, Fuller E, Handt R, et al. Instrument-assisted soft tissue mobilization in healthy young adult males mobilizes tissue-resident mesenchymal stem cells into circulation. J Orthop Sports Phys Ther. 2016;46(1):A107.

172. Lambert M, Hitchcock R, Lavallee K, et al. The effects of instrument-assisted soft tissue mobilization compared to other interventions on pain and function: a systematic review. Phys Ther Rev. 2017:1-10.

173. Thompson J, Crowder L, Le D, Roethele A. Efficacy of Instrument-assisted soft tissue mobilization for the treatment of musculotendinous injuries: A systematic review. J Orthop Sports Phys Ther. 2018;48(1):187.

174. Allenby F, Boardman L, Pflug JJ, Calnan JS. Effects of external pneumatic intermittent compression on fibrinolysis in man. Lancet Lond Engl. 1973;2(7843):1412-1414. doi:10.1016/s0140-6736(73)92802-x

175. Cantu RI, Grodin AJ. Myofascial Manipulation: Theory and Clinical Application. Aspen Publishers; 1992.

176. Chamberlain GJ. Cyriax's Friction Massage: A Review. J Orthop Sports Phys Ther. 1982;4(1):16-22. doi:10.2519/jospt.1982.4.1.16

177. Cottingham JT, Porges SW, Lyon T. Effects of soft tissue mobilization (Rolfing pelvic lift) on parasympathetic tone in two age groups. Phys Ther. 1988;68(3):352-356. doi:10.1093/ptj/68.3.352

178. Cottingham JT, Porges SW, Richmond K. Shifts in pelvic inclination angle and parasympathetic tone produced by Rolfing soft tissue manipulation. Phys Ther. 1988;68(9):1364-1370. doi:10.1093/ptj/68.9.1364

179. Evans EB, Eggers GWN, Butler JK, Blumel J. Experimental Immobilization and Remobilization of Rat Knee Joints. JBJS. 1960;42(5):737.

180. Goats GC. Massage--the scientific basis of an ancient art: Part 1. The techniques. $\mathrm{Br} J$ Sports Med. 1994;28(3):149-152. doi:10.1136/bjsm.28.3.149 
181. Grodin A, Cantu R. Myofascial Manipulation. Marietta, GA: Institute of Graduate Physical Therapy; 1991.

182. Ladd MP, Kottke FJ, Blanchard RS. Studies of the effect of massage on the flow of lymph from the foreleg of the dog. Arch Phys Med Rehabil. 1952;33(10):604-612.

183. McGonigle T, Matley K. Soft tissue treatment and muscle stretching. J Man Manip Ther. 94(2):55-62.

184. Morgan D. Principles of soft tissue treatment. J Man Manip Ther. 1994;2(2):63-65.

185. Wakim KG, Martin GM. The effects of massage on the circulation in normal and paralyzed extremities. Arch Phys Med Rehabil. 1949;30(3):135-144.

186. Wiktorsson-Möller M, Oberg B, Ekstrand J, Gillquist J. Effects of warming up, massage, and stretching on range of motion and muscle strength in the lower extremity. Am J Sports Med. 1983;11(4):249-252. doi:10.1177/036354658301100412

187. Wolfson H. Studies on the effect of physical therapeutic procedures on function and structure. J Am Med Assoc. 1931;31(6):2018-2020.

188. Khan KM, Scott A. Mechanotherapy: how physical therapists' prescription of exercise promotes tissue repair. Br J Sports Med. 2009;43(4):247-252.

doi:10.1136/bjsm.2008.054239

189. Holtz B, Davey K, Bayliss A, Loghmani M. A conservative manual therapy approach using instrument-assisted soft tissue mobilization for the treatment of bilateral plantar-fasciitis: a case series. J Orthop Sports Phys Ther. 2012;42(1):95.

190. Daniels CJ, Morrell AP. Chiropractic management of pediatric plantar fasciitis: a case report. J Chiropr Med. 2012;11(1):58-63. doi:10.1016/j.jcm.2011.06.009

191. Garrett T, Neibert P. Effect of Graston Technique as a treatment for patients with chronic plantar fasciosis: a randomized controlled trial. J Athl Train. 2014;49(3):57-58.

192. Ploski M, Hinkeldey N. Evidence-Based Treatment of Achilles Tendinosis with InstrumentAssisted Soft-Tissue Mobilization Combined with Eccentric Exercise: A Case Report. $J$ Athl Train. 2015;50(9):985.

193. Phipps R, Carney S, Loghmani M, Bayliss A. An innovative manual therapy approach for the treatment of patients with Achilles tendinopathy: a case series. J Orthop Sports Phys Ther. 2011;41(1):65.

194. Papa JA. Two cases of work-related lateral epicondylopathy treated with Graston Technique ${ }^{\circledR}$ and conservative rehabilitation. J Can Chiropr Assoc. 2012;56(3):192-200.

195. White KE. High hamstring tendinopathy in 3 female long distance runners. J Chiropr Med. 2011;10(2):93-99. doi:10.1016/j.jcm.2010.10.005 
196. Terry Loghmani M, Bayliss AJ, Clayton G, Gundeck E. Successful treatment of a guitarist with a finger joint injury using instrument-assisted soft tissue mobilization: a case report. $J$ Man Manip Ther. 2015;23(5):246-253. doi:10.1179/2042618614Y.0000000089

197. Clayton J, McCracken C, Gross A, Loghmani M. Treatment of peroneal tendonitis and plantar fasciitis using instrument-assisted soft tissue mobilization: a case report. J Orthop Sports Phys Ther. 2012;42(1):94.

198. Faltus J, Boggess B, Bruzga R. The use of diagnostic musculoskeletal ultrasound to document soft tissue treatment mobilization of a quadriceps femoris muscle tear: a case report. Int J Sports Phys Ther. 2012;7(3):342-349.

199. Bayliss AJ, Klene FJ, Gundeck EL, Loghmani MT. Treatment of a patient with post-natal chronic calf pain utilizing instrument-assisted soft tissue mobilization: a case study. J Man Manip Ther. 2011;19(3):127-134. doi:10.1179/2042618611Y.0000000006

200. Miller S, Lee G, Goodwin C, Greene J, Siyufy A, Aron A. Self-applied versus clinicianapplied treatment for myofascial trigger points. J Orthop Sports Phys Ther. 2018;48(1):154.

201. Heinecke M, Thuesen S, Stow R. Graston Technique on shoulder motion in overhead athletes. J Undergrad Kinesiol Res. 2014;10(1):27-39.

202. Heyer K, Docherty C, Donahue M, Schrader J. Effect of implement assisted soft tissue mobilization techniques on iliotibial band tightness. J Athl Train. 2012;47(3):128.

203. Jöbsis FF. Noninvasive, infrared monitoring of cerebral and myocardial oxygen sufficiency and circulatory parameters. Science. 1977;198(4323):1264-1267.

204. Crenshaw AG, Elcadi GH, Hellstrom F, Mathiassen SE. Reliability of near-infrared spectroscopy for measuring forearm and shoulder oxygenation in healthy males and females. Eur J Appl Physiol. 2012;112(7):2703-2715. doi:10.1007/s00421-011-2244-1

205. Chance B, Nioka S, Kent J, et al. Time-resolved spectroscopy of hemoglobin and myoglobin in resting and ischemic muscle. Anal Biochem. 1988;174(2):698-707.

206. Sako T, Hamaoka T, Higuchi H, Kurosawa Y, Katsumura T. Validity of NIR spectroscopy for quantitatively measuring muscle oxidative metabolic rate in exercise. $J$ Appl Physiol Bethesda Md 1985. 2001;90(1):338-344. doi:10.1152/jappl.2001.90.1.338

207. Hamaoka T, McCully KK, Quaresima V, Yamamoto K, Chance B. Near-infrared spectroscopy/imaging for monitoring muscle oxygenation and oxidative metabolism in healthy and diseased humans. J Biomed Opt. 2007;12(6):062105. doi:10.1117/1.2805437

208. Wolf M, Ferrari M, Quaresima V. Progress of near-infrared spectroscopy and topography for brain and muscle clinical applications. J Biomed Opt. 2007;12(6):062104. doi: $10.1117 / 1.2804899$ 
209. Southern WM, Ryan TE, Reynolds MA, McCully K. Reproducibility of near-infrared spectroscopy measurements of oxidative function and postexercise recovery kinetics in the medial gastrocnemius muscle. Appl Physiol Nutr Metab Physiol Appl Nutr Metab. 2014;39(5):521-529. doi:10.1139/apnm-2013-0347

210. Mancini DM, Bolinger L, Li H, Kendrick K, Chance B, Wilson JR. Validation of nearinfrared spectroscopy in humans. J Appl Physiol Bethesda Md 1985. 1994;77(6):27402747. doi:10.1152/jappl.1994.77.6.2740

211. Wilson JR, Mancini DM, McCully K, Ferraro N, Lanoce V, Chance B. Noninvasive detection of skeletal muscle underperfusion with near-infrared spectroscopy in patients with heart failure. Circulation. 1989;80(6):1668-1674.

212. Ferrari M, Mottola L, Quaresima V. Principles, techniques, and limitations of near infrared spectroscopy. Can J Appl Physiol Rev Can Physiol Appl. 2004;29(4):463-487.

213. Lucero AA, Addae G, Lawrence W, et al. Reliability of muscle blood flow and oxygen consumption response from exercise using near-infrared spectroscopy. Exp Physiol. 2018;103(1):90-100. doi:10.1113/EP086537

214. Ryan TE, Southern WM, Reynolds MA, McCully KK. A cross-validation of near-infrared spectroscopy measurements of skeletal muscle oxidative capacity with phosphorus magnetic resonance spectroscopy. J Appl Physiol Bethesda Md 1985. 2013;115(12):17571766. doi:10.1152/japplphysiol.00835.2013

215. Hamaoka T, Iwane H, Shimomitsu T, et al. Noninvasive measures of oxidative metabolism on working human muscles by near-infrared spectroscopy. J Appl Physiol Bethesda Md 1985. 1996;81(3):1410-1417. doi:10.1152/jappl.1996.81.3.1410

216. Hampson NB, Piantadosi CA. Near infrared monitoring of human skeletal muscle oxygenation during forearm ischemia. J Appl Physiol Bethesda Md 1985. 1988;64(6):24492457. doi:10.1152/jappl.1988.64.6.2449

217. De Blasi RA, Ferrari M, Natali A, Conti G, Mega A, Gasparetto A. Noninvasive measurement of forearm blood flow and oxygen consumption by near-infrared spectroscopy. J Appl Physiol Bethesda Md 1985. 1994;76(3):1388-1393. doi:10.1152/jappl.1994.76.3.1388

218. Homma S, Eda H, Ogasawara S, Kagaya A. Near-infrared estimation of O2 supply and consumption in forearm muscles working at varying intensity. J Appl Physiol Bethesda Md 1985. 1996;80(4):1279-1284. doi:10.1152/jappl.1996.80.4.1279

219. De Blasi RA, Almenrader N, Aurisicchio P, Ferrari M. Comparison of two methods of measuring forearm oxygen consumption (VO2) by near infrared spectroscopy. J Biomed Opt. 1997;2(2):171-175. doi:10.1117/12.269893 
220. Van Beekvelt MC, Colier WN, Wevers RA, Van Engelen BG. Performance of near-infrared spectroscopy in measuring local $\mathrm{O}(2)$ consumption and blood flow in skeletal muscle. $J$ Appl Physiol Bethesda Md 1985. 2001;90(2):511-519. doi:10.1152/jappl.2001.90.2.511

221. Malagoni AM, Felisatti M, Mandini S, et al. Resting muscle oxygen consumption by nearinfrared spectroscopy in peripheral arterial disease: A parameter to be considered in a clinical setting? Angiology. 2010;61(6):530-536. doi:10.1177/0003319710362975

222. Binzoni T, Cooper CE, Wittekind AL, et al. A new method to measure local oxygen consumption in human skeletal muscle during dynamic exercise using near-infrared spectroscopy. Physiol Meas. 2010;31(9):1257-1269. doi:10.1088/0967-3334/31/9/014

223. Belardinelli R, Barstow TJ, Porszasz J, Wasserman K. Changes in skeletal muscle oxygenation during incremental exercise measured with near infrared spectroscopy. Eur $J$ Appl Physiol. 1995;70(6):487-492.

224. Bhambhani YN. Muscle oxygenation trends during dynamic exercise measured by near infrared spectroscopy. Can J Appl Physiol Rev Can Physiol Appl. 2004;29(4):504-523.

225. Brizendine JT, Ryan TE, Larson RD, McCully KK. Skeletal muscle metabolism in endurance athletes with near-infrared spectroscopy. Med Sci Sports Exerc. 2013;45(5):869875. doi:10.1249/MSS.0b013e31827e0eb6

226. Tew GA, Ruddock AD, Saxton JM. Skin blood flow differentially affects near-infrared spectroscopy-derived measures of muscle oxygen saturation and blood volume at rest and during dynamic leg exercise. Eur J Appl Physiol. 2010;110(5):1083-1089. doi:10.1007/s00421-010-1596-2

227. Sjøgaard G, Rosendal L, Kristiansen J, et al. Muscle oxygenation and glycolysis in females with trapezius myalgia during stress and repetitive work using microdialysis and NIRS. Eur J Appl Physiol. 2010;108(4):657-669. doi:10.1007/s00421-009-1268-2

228. Chen B, Amory DW. Noninvasive measurement of forearm oxygen consumption by nearinfrared spectroscopy. J Appl Physiol Bethesda Md 1985. 1995;78(4):1617-1618. doi:10.1152/jappl.1995.78.4.1617

229. Edwards AD, Richardson C, van der Zee P, et al. Measurement of hemoglobin flow and blood flow by near-infrared spectroscopy. J Appl Physiol Bethesda Md 1985. 1993;75(4):1884-1889. doi:10.1152/jappl.1993.75.4.1884

230. Homma S, Fukunaga T, Kagaya A. Influence of adipose tissue thickness on near infrared spectroscopic signal in the measurement of human muscle. J Biomed Opt. 1996;1(4):418424. doi:10.1117/12.252417

231. Ryan TE, Erickson ML, Brizendine JT, Young H-J, McCully KK. Noninvasive evaluation of skeletal muscle mitochondrial capacity with near-infrared spectroscopy: correcting for blood volume changes. J Appl Physiol Bethesda Md 1985. 2012;113(2):175-183. doi:10.1152/japplphysiol.00319.2012 
232. Colier WN, Meeuwsen IB, Degens H, Oeseburg B. Determination of oxygen consumption in muscle during exercise using near infrared spectroscopy. Acta Anaesthesiol Scand Suppl. 1995;107:151-155.

233. Miura H, McCully K, Nioka S, Chance B. Relationship between muscle architectural features and oxygenation status determined by near infrared device. Eur J Appl Physiol. 2004;91(2-3):273-278. doi:10.1007/s00421-003-0964-6

234. Asha SE, Pryor R. Validation of a method to assess range of motion of the cervical spine using a tape measure. J Manipulative Physiol Ther. 2013;36(8):538-545. doi:10.1016/j.jmpt.2013.07.005

235. Hsieh CY, Yeung BW. Active neck motion measurements with a tape measure*. J Orthop Sports Phys Ther. 1986;8(2):88-90.

236. Maksymowych WP, Mallon C, Richardson R, et al. Development and validation of a simple tape-based measurement tool for recording cervical rotation in patients with ankylosing spondylitis: comparison with a goniometer-based approach. J Rheumatol. 2006;33(11):2242-2249.

237. Alaranta H, Hurri H, Heliövaara M, Soukka A, Harju R. Flexibility of the spine: normative values of goniometric and tape measurements. Scand J Rehabil Med. 1994;26(3):147-154.

238. Sciotti VM, Mittak VL, DiMarco L, et al. Clinical precision of myofascial trigger point location in the trapezius muscle. Pain. 2001;93(3):259-266.

239. Fischer AA. Pressure algometry over normal muscles. Standard values, validity and reproducibility of pressure threshold. Pain. 1987;30(1):115-126.

240. Keele KD. Pain-sensitivity tests; the pressure algometer. Lancet Lond Engl. 1954;266(6813):636-639.

241. Merskey H, Gillis A, Marszalek KS. A clinical investigation of reactions to pain. J Ment Sci. 1962;108:347-355.

242. Merskey H, Spear FG. The Reliability of the Pressure Algometer. Br J Soc Clin Psychol. 1964;3(2):130-136. doi:10.1111/j.2044-8260.1964.tb00415.x

243. Reeves JL, Jaeger B, Graff-Radford SB. Reliability of the pressure algometer as a measure of myofascial trigger point sensitivity. Pain. 1986;24(3):313-321.

244. Yamagata S, Ishikawa M, Saijo M, Fukushima S, Yamanobe K. A diagnostic re-evaluation of electric skin resistance, skin temperature and deeper tenderness in patients with abdominal pain. Tohoku J Exp Med. 1976;118 Suppl:183-189.

245. Cheatham SW, Kolber MJ, Mokha GM, Hanney WJ. Concurrent validation of a pressure pain threshold scale for individuals with myofascial pain syndrome and fibromyalgia. $J$ Man Manip Ther. 2018;26(1):25-35. doi:10.1080/10669817.2017.1349592 
246. Ylinen J, Nykänen M, Kautiainen H, Häkkinen A. Evaluation of repeatability of pressure algometry on the neck muscles for clinical use. Man Ther. 2007;12(2):192-197.

doi:10.1016/j.math.2006.06.010

247. Chesterton LS, Sim J, Wright CC, Foster NE. Interrater reliability of algometry in measuring pressure pain thresholds in healthy humans, using multiple raters. Clin J Pain. 2007;23(9):760-766. doi:10.1097/AJP.0b013e318154b6ae

248. Nussbaum EL, Downes L. Reliability of clinical pressure-pain algometric measurements obtained on consecutive days. Phys Ther. 1998;78(2):160-169. doi:10.1093/ptj/78.2.160

249. Persson AL, Brogårdh C, Sjölund BH. Tender or not tender: test-retest repeatability of pressure pain thresholds in the trapezius and deltoid muscles of healthy women. $J$ Rehabil Med. 2004;36(1):17-27.

250. Schory A, Bidinger E, Wolf J, Murray L. A SYSTEMATIC REVIEW OF THE EXERCISES THAT PRODUCE OPTIMAL MUSCLE RATIOS OF THE SCAPULAR STABILIZERS IN NORMAL SHOULDERS. Int J Sports Phys Ther. 2016;11(3):321-336.

251. Pizzari T, Wickham J, Balster S, Ganderton C, Watson L. Modifying a shrug exercise can facilitate the upward rotator muscles of the scapula. Clin Biomech Bristol Avon. 2014;29(2):201-205. doi:10.1016/j.clinbiomech.2013.11.011

252. Ekstrom RA, Donatelli RA, Soderberg GL. Surface electromyographic analysis of exercises for the trapezius and serratus anterior muscles. J Orthop Sports Phys Ther. 2003;33(5):247258. doi:10.2519/jospt.2003.33.5.247

253. Park S, Nho H, Chang M-J, Kim J-K. Electromyography activities for shoulder muscles over various movements on different torque changes. Eur J Sport Sci. 2012;12(5):408-417. doi:10.1080/17461391.2011.566375

254. Uhl TL, Muir TA, Lawson L. Electromyographical assessment of passive, active assistive, and active shoulder rehabilitation exercises. PM R. 2010;2(2):132-141. doi:10.1016/j.pmrj.2010.01.002

255. Jaeger B. Myofascial trigger point pain. Alpha Omegan. 2013;106(1-2):14-22.

256. Cheatham SW, Baker R, Kreiswirth E. INSTRUMENT ASSISTED SOFT-TISSUE MOBILIZATION: A COMMENTARY ON CLINICAL PRACTICE GUIDELINES FOR REHABILITATION PROFESSIONALS. Int J Sports Phys Ther. 2019;14(4):670-682. 